\title{
Al1103 088725
}

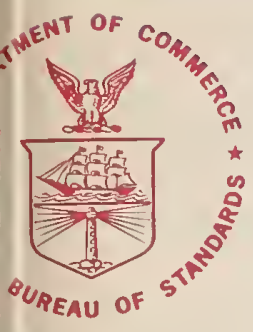

\section{NBS SPECIAL PUBLICATION 454}

U.S. DEPARTMENT OF COMMERCE / National Bureau of Standards

An Annotated Bibliography of Compiled Thermodynamic Data Sources

\section{for Biochemical and}

Aqueous Systems (1930 to 1975)

\section{Equilibrium, Enthalpy,}

Heat Capacity, and Entropy Data

$Q C$
100
.$U 57$
$N 0,454$
1976
$C .2$


The National Bureau of Standards ${ }^{1}$ was established by an act of Congress March 3, 1901. The Bureau's overall goal is to strengthen and advance the Nation's science and technology and facilitate their effective application for public benefit. To this end, the Bureau conducts research and provides: (1) a basis for the Nation's physical measurement system, (2) scientific and technological services for industry and government, (3) a technical basis for equity in trade, and (4) technical services to promote public safety. The Bureau consists of the Institute for Basic Standards, the Institute for Materials Research, the Institute for Applied Technology, the Institute for Computer Sciences and Technology, and the Office for Information Programs.

THE INSTITUTE FOR BASIC STANDARDS provides the central basis within the United States of a complete and consistent system of physical measuremept; coordinates that system with measurement systems of other nations; and furnishes essential services leading to accurate and uniform physical measurements throughout the Nation's scientific community, industry, and commerce. The Institute consists of the Office of Measurement Services, the Office of Radiation Measurement and the following Center and divisions:

Applied Mathematics - Electricity - Mechanics - Heat - Optical Physics - Center for Radiation Research: Nuclear Sciences; Applied Radiation - Laboratory Astrophysics ${ }^{2}$ - Cryogenics ${ }^{2}$ - Electromagnetics " - Time and Frequency $\%$

THE INSTITUTE FOR MATERIALS RESEARCH conducts materials research leading to improved methods of measurement, standards, and data on the properties of well-characterized materials needed by industry, commerce, educational institutions, and Government; provides advisory and research services to other Government agencies; and develops, produces, and distributes standard reference materials. The Institute consists of the Office of Standard Reference Materials, the Office of Air and Water Measurement, and the following divisions:

Analytical Chemistry - Polymers - Metallurgy - Inorganic Materials — Reactor Radiation - Physical Chemistry.

THE INSTITUTE FOR APPLIED TECHNOLOGY provides technical services to promote the use of available technology and to facilitate technological innovation in industry and Government; cooperates with public and private organizations leading to the development of technological standards (including mandatory safety standards), codes and methods of test; and provides technical advice and services to Government agencies upon request. The Institute consists of the following divisions and Centers:

Standards Application and Analysis - Electronic Technology - Center for Consumer Product Technology: Product Systems Analysis; Product Engineering - Center for Building Technology: Structures, Materials, and Life Safety; Building Environment; Technical Evaluation and Application - Center for Fire Research: Fire Science; Fire Safety Engineering.

THE INSTITUTE FOR COMPUTER SCIENCES AND TECHNOLOGY conducts research and provides technical services designed to aid Government agencies in improving cost effectiveness in the conduct of their programs through the selection, acquisition, and effective utilization of automatic data processing equipment; and serves as the principal focus within the executive branch for the development of Federal standards for automatic data processing equipment, techniques, and computer languages. The Institute consists of the following divisions:

Computer Services - Systems and Software - Computer Systems Engineering — Information Technology.

THE OFFICE FOR INFORMATION PROGRAMS promotes optimum dissemination and accessibility of scientific information generated within NBS and other agencies of the Federal Government; promotes the development of the National Standard Reference Data System and a system of information analysis centers dealing with the broader aspects of the National Measurement System; provides appropriate services to ensure that the NBS staff has optimum accessibility to the scientific information of the world. The Office consists of the following organizational units:

Office of Standard Reference Data - Office of Information Activities — Office of Technical Publications - Library - Office of International Relations - Office of International Standards.

Headquarters and Laboratories at Gaithersburg, Maryland, unless otherwise noted; mailing address IVashington. D.C. 20234.

¿ Located at Boulder. Colorado 80302 


\section{6}

\section{An Annotated Bibliography of Compiled Thermodynamic Data Sources for Biochemical and Aqueous Systems (1930 to 1975)}

Equilibrium, Enthalpy, Heat Capacity, and Entropy Data

George T. Armstrong and Robert N. Goldberg

Institute for Materials Research

National Bureau of Standards

Washington, D.C. 20234

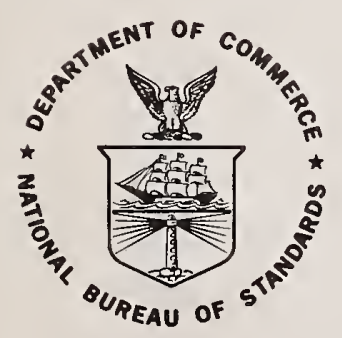

U.S. DEPARTMENT OF COMMERCE, Elliot L. Richardson, Secretary

Edward O. Vetter, Under Secretary

Dr. Betsy Ancker-Johnson, Assistant Secrefary for Science and Technology

NATIONAL BUREAU OF STANDARDS, Ernest Ambler, Acting Director

Issued September 1976 


\section{Library of Congress Cataloging in Publication Data}

Armstrong, George Thomson, 1916-

An annotated bibliography of compiled thermodynamic data sources for biochemical and aqueous systems (1930 to 1975)

(National Bureau of Standards special publication ; 454)

Includes indexes.

Supt. of Docs. no.: C13.10:454

1. Thermodynamics--Bibliography. I. Goldberg, Robert N., joint author. II. United States. National Bureau of Standards. Institute for Materials Research. III. Title: An annotated bibliography of compiled thermodynamic data sources . . . . IV. Series: United States. National Bureau of Standards. Special publication ; 454.

QC100.U57 no.45 4 [Z5524.T4] [QD51 1] 602'.ls [016.541'36] 76-608259

\section{National Bureau of Standards Special Publication 454}

Nat. Bur. Stand. (U.S.), Spec. Publ. 454, 67 pages (Sept. 1976) CODEN: XNBSAV

\section{U.S. GOVERNMENT PRINTING OFFICE}

WASHINGTON: 1976

For sale by the Superintendent of Documents, U.S. Government Printing Office, Washington, D.C. 20402 (Order by SD Catalog No. C13.10:454). Stock No. 003-003-01666-7 Price \$1.65

(Add 25 percent additional for other than U.S. mailing). 
Foreword

The National Standard Reference Data System was established in 1963 for the purpose of promoting the critical evaluation and dissemination of numerical data of the physical sciences. The program is coordinated by the office of Standard Reference Data of the National Bureau of Standards but involves the efforts of many groups in universities, government laboratories, and private industry. The primary aim of the program is to provide compilations of critically evaluated physical and chemical property data. These tables are published in the Journal of Physical and Chemical Reference Data, in the NSRDS-NBS series of the National Bureau of Standards, and through other appropriate channels.

The task of critical evaluation is carried out in various data centers, each with a well-defined technical scope. A necessary preliminary step to the critical evaluation process is the retrieval from the world scientific literature of all papers falling within the scope of the center. Each center, therefore, builds up a comprehensive well-indexed bibliographical file which forms the base for the evaluation task. Bibliographies derived from these files are published when they appear to be of value to research workers and othersinterested in the particular technical or programmatic area.

The present effort provides a useful collection of data sources required in solving problems associated with water pollution. The properties data extracted from the bibliographic sources cited in this document will help classify the behavior of many of the specific pollutants found in the water environment.

Further information on NSRDS and the publications which form the primary output of the program may be obtained by writing to the Office of Standard Reference Data, National Bureau of Standards, Washington, D.C. 20234

David R, Lide, Jr., Chief

Office of Standard Reference Data 
Abstract ............................ . . v Introduction. . . . . . . . . . . . . . . . . . . . . . vi Bibliography. . . . . . . . . . . . . . . . . . . . . 1 Author Index. . . . . . . . . . . . . . . . . . 35 Subject Index . . . . . . . . . . . . . . . . . . . . 39 
"The cold tables of physical and chemical constants, the base equations in textbooks, form the hardcore, the residue distilled from individual triumphs of insight, checked and crosschecked by the multiple testimony of general experience"

Gerald Holton

American Scientist, 41 ,

$93(1953)$

\section{ABSTRACT}

Contained herein is a selected and annotated bibliography of sources of compiled and evaluated chemical thermodynamic data relevant to biochemical and aqueous systems. The principal thermodynamic properties considered herein are Gibbs energy and equilibrium data, enthalpies of formation and reaction, heat capacities and entropies, and the corresponding partial molal properties. Derived quantities used in calculating the above are also included. Transport and mechanical data have also been identified to a lesser degree. Included in the annotations to the data sources are brief descriptions of the types of properties tabulated, the classes of materials dealt with, and the degree of completeness of the compilations.

Keywords: Aqueous systems; bibliography; biochemical systems; enthalpy data; entropy data; equilibrium data; Gibbs energy data; heat capacity data; partial molal properties; thermochemistry; thermodynamics; review articles; water pollution. 
There is a growing need for reliable thermodynamic data for both scientific and practical purposes. However, the existence of a desired piece of data in the primary literature does not guarantee its recovery by an interested user. Indeed the recovery process may be a decidely non-trivial as well as a time consuming matter. At one time this problem was, in large part, managed by periodic review articles, monographs, and the International Critical Tables. The NSRDS, CODATA, and other coordinating organizations are providing current compilations. However, the preparation of new reviews is sufficiently complex that there are at any given time many subject areas that do not have current compilations available. In this circumstance earlier reviews are an important resource for the technologist or scientist. Unfortunately, the proliferation of such works and the enormity of the available literature have made even the recovery of review and compilation articles a matter of some difficulty. It is to help solve this problem for one small part of our science that we have prepared this annotated bibliography of thermodynamic data sources relevant to biochemical and aqueous systems. These two areas are mutually complementary. In environmental problems such as water quality control, and in the utilization of aqueous sys tems with respect to energy resources and the processing of material resources, the aqueous systems of interest very of ten include the same substances and require the same information as in the study of biochemical systems. In addition to information on the aqueous solutions, the properties of the pure substances are of ten required in order to establish reference points for interrelating various systems. Thus, this bibliography is a selective listing of sources of thermodynamic information for pure substances and aqueous solutions, selected for their particular relevance to these kinds of problems .

The entries of the bibliography are listed in alphabetical order by leading author. A brief description of the contents of each is given to permit the reader to select those references which will most directly apply to his own needs. Some of the compilations (I) were prepared specifically for use in biochemical or aqueous solution thermodynamics, while others were prepared for a more general thermodynamic audience, but also contain substantial amounts of data valuable to these two areas; others (III) are of tangential interest and contain some, but comparatively limited amounts of data specific to either biochemical or aqueous systems. These three degrees of relevance are indicated by the Roman numerals I, II, and III, respectively. Thus, each entry in this bibliography will have associated with it two Roman numerals, the first referring to its relevancy with regards to biochemical systems and the latter with regard to aqueous systems. This bibliography is intended to be fairly complete with respect to categories I and II but makes no attempt at completeness in category III. The authors would appreciate comments from interested readers concerning data sources omitted from this bibliography.

The alphabetical subject index that follows the main section of this bibliography gives an indication of thermodynamic properties, physical or chemical processes, classes of substances, and, in a few cases, individual substances for which information is to be found herein. It is not practical to give an exhaustive index to the contents of the individual references, hence the absence of a piece of information in the index does not necessarily mean its absence in the references. This is particularly true with respect to particular substances, which the reader should assume are not listed except by chance of title or abstract.

Grateful acknowledgment is made to Ms. Gail R. Janes who aided in the preparation of an earlier and more limited version of this material (National Bureau of Standards Report 74-535 (1974)), and to several colleagues, and in particular Dr. W. H. Evans (NBS), who made helpful comments on this and on the earlier bibliography. This work was supported, in part by the office of Standard Reference Data of the National Bureau of Standards. 
1. Alberty, R. A .

I, II

Standard Gibbs Free Energy, Enthalpy, and Entropy Changes as a Function of $\mathrm{pH}$, and pMg for Several Reactions Involving Adenosine Phosphates

Journal of Biological Chemistry, 244, 3290 (1969)

The standard Gibbs energy, enthalpy, and entropy changes for the hydrolysis of adenosine-5'triphosphate to adenosine-5'-diphosphate are computed as a function of $\mathrm{pH}$ and magnesium ion concentration. A critical evaluation of the relevant 1iterature data is included.

$* * * * * * * * * *$

2. Armstrong, G. T., Domalski, E. S., Furukawa, G. T., Reilly, M. L., I, II Wilhoit, R. C., and others

A Survey of Thermodynamic Properties of the Compounds of the Elements CHNOPS - A Series of Eighteen Reports

(National Bureau of Standards Reports No. 8521, 8595, 8641, 8906, 8992, 9043, 9089, $9374,9449,9501,9553,9607,9883,9968,10070$, and 10291, published during the years 1964 to 1970 , U. S. Department of Commerce, Washington, DC 20234)

This series of reports is a survey of the thermodynamic properties of selected compounds of biological importance containing the elements carbon, hydrogen, nitrogen, oxygen, phosphorous, and sulfur. Included in these reports are heat capacity data; heats and Gibbs energies of formation; vapor pressure data; tables of thermodynamic functions; Gibbs energies, entropies and enthalpies of solution and dilution; and thermodynamic properties of mixed solvent systems. References to sources of data in the literature are included.

$$
* * * * * * * * * * *
$$

3. Ashcroft, S. J., and Mortimer, C. T.

Thermochemistry of Transition Metal Complexes

II, I

(Academic Press, London, New York, 1970)

This book surveys the 1iterature to 1968 on energy changes for processes involving transition metal complexes including both organic and inorganic ligands. A critical review of the thermochemical data for over 1500 systems of complexes is given. Comparable data from various sources are shown in juxtaposition. Values of $\Delta H, \Delta G$, and $\Delta S$ for various stages of complex formation are usually listed for processes in aqueous solution. $\Delta E_{\mathrm{f}}{ }^{\circ}, \Delta G_{\mathrm{f}}{ }^{\circ}, \Delta S_{\mathrm{f}}{ }^{\circ}$ for crystalline complex substances are given where available. In many instances correlations of the data for various metals with a single ligand, and for varlous related complexes of a given metal, are given graphically or by means of bond-energy estimates based on the data.

$$
* * * * * * * * * * *
$$

Baes, C. F., Jr., and Mesmer, R. E. -- see entry no. 93

$$
* * * * * * * * * *
$$

Bates, R. G. -- see entry no. 94

$$
* * * * * * * * * * *
$$

4. Battino, R.

Volume Changes on Mixing for Binary Mixtures of Liquids

III, I

Chemical Reviews, $\underline{71}, 5$ (1971)

This critical and extensive review deals with both the volume changes associated with the mixing of binary mixtures of liquids and partial molal volumes at infinite dilution of various solvent systems, aqueous and non-aqueous. The temperature range cited is that at which the experimental measurements have been performed. Included is a detailed discussion of the experimental methods used for measurements and associated theoretical developments. The coverage of the available literature appears to be very thorough. There are 427 references to the primary literature. 
5. Battino, R., and Clever, H. L.

III, I

The Solubility of Gases in Liquids

Chemical Reviews, 66, 395 (1966)

This thorough and detailed review contains a detailed discussion of experimental methods for the measurement of gas solubilities in all types of liquids, including water. Tabulated are the solubilities of oxygen, nitrogen, and argon in water at one atmosphere pressure and from 0 to $50{ }^{\circ} \mathrm{C}$. Also to be found herein is an extensive table listing sources of gas solubility data in the primary literature. Although the tables do not give selected values, the authors have given their assessment of the rellability of the data to be found in the listed sources by means of a coding scheme. There are 686 references to the primary literature.

More recently, E. Wilhelm and R. Battino (Chemical Reviews, 73, 1 (1973)) have critically evaluated the solubilities and enthalpies of solution of gases in non-aqueous solvent systems.

$\star \star * * * * * * * * *$

6. Benson, S. W.

Thermochemical Kinetics

III, III

Methods for the Estimation of Thermochemical Data and Rate Parameters

(John Wiley and Sons, Inc., New York, London, Sydney, 1968)

This monograph gives tables of necessary data and descriptions of methods of their use for calculating $\Delta H_{\mathrm{f}}, \mathrm{Cp}$, and $S$ at $25^{\circ} \mathrm{C}$ for gas phase molecules and radicals and for extrapolating them to higher temperatures. The procedures can be applied to hydrocarbons, oxygen-containing compounds, nitrogen-containing compounds, haloalkanes, organo-sulfur compounds, and organo-metallic compounds, and deal principally with organic compounds.

$\star * * * * * * * *$

7. Benson, S. W., Cruickshank, F. R., Golden, D. M., Haugen, G. R., III, III

O'Neal, H. E., Rogers, A. S., Shaw, R., and Walsh, R.

Additivity Rules for the Estimation of Thermochemical Properties

Chemical Reviews, 69, 279-324 (1969)

This lengthy technical article gives procedures for calculating the properties $\Delta H^{\circ}, S^{\circ}$, $C_{\mathrm{p}}{ }^{\circ}$, for organic compounds in the gas phase. Parameters for calculating $C_{\mathrm{p}}$ are given for the temperature range from 300 to $1500 \mathrm{~K}$. The availability of $\mathrm{Cp}$ as a function of temperature allow: calculation of $\Delta H_{f}{ }^{\circ}$ and $S^{\circ}$ at the same temperatures. The necessary constants for making the calculations are given for individual chemical groupings in some 38 tables. Many classes of functional groups and molecular conformations are included. Examples are given comparing calculated and observed values. Agreements of $1 \mathrm{kcal} \cdot \mathrm{mol}^{-1}\left(4 \mathrm{~kJ} \cdot \mathrm{mol}^{-1}\right)$ or better in $\Delta H_{\mathrm{f}}^{\circ}$ and $1 \mathrm{cal} \cdot \mathrm{mol}^{-1} \cdot \mathrm{K}^{-1}\left(4 \mathrm{~J} \cdot \mathrm{mol}^{-1} \cdot \mathrm{K}^{-1}\right)$ or better in $C_{\mathrm{p}}{ }^{\circ}$ and $S^{\circ}$ are generally found.

$* * * * * * * * *$

8. Bichowsky, F. R., and Rossini, F. D.

II, II

The Thermochemistry of the Chemical Substances

(Reinhold Publishing Corporation, New York, 1936)

Although outdated, this book still provides useful references to the older thermochemical literature. Tabulated are $\Delta H_{f}{ }^{\circ}$ values for the elements and their compounds, with the data for carbon-containing compounds being terminated at two carbon atoms. It should be noted that the data pertain to a temperature of $18{ }^{\circ} \mathrm{C}$ and to diamond, rather than graphite, as the standard state for carbon. 
9. Bondi, A.

III, III

Physical Properties of Molecular Crystals, Liquids, and Glasses

(John Wiley and Sons, Inc., New York, London, Sydney, 1968)

This monograph is designed for the use of chemical engineers to estimate physical properties needed in design calculations, as well as of physical chemists and synthetic chemists who need to understand the relationship between structure and physical properties. Correlations of several kinds are described in the text. These are then restated as methods for estimation of the properties.

Substances considered include non-polar and polar gases, non-polar and polar 1iquids, associated liquids, crystalline solids, glasses, polymers, and polymer melts, as well as others. Procedures given include many variants, depending upon the properties given as initial information. Among the properties for which procedures are given are: density, heat capacity, enthalpy, entropy, enthalpy and entropy of fusion, enthalpy of vaporization, vapor pressure, cubical thermal expansion coefficient, bulk modulus, Young's modulus compressibility, thermal conductivity, rotational diffusion constant, relaxation times, mass diffusion, viscosity, and others.

$* * * * * * * * * *$

Boublik, T., Fried, V., and Hala, E. - see entry no. 95

$\star * * * * * * * * *$

10. Brown, H. D. (editor)

I, II

Biochemical Microcalorimetry

(Academic Press, New York, London, 1969)

This book contains seventeen articles on subjects concerning heat measurements and their relationship to biology and biochemistry. Several of the articles contain tabulations of data:

Author (s)

R. C. Wilhoit

Title of Article

Thermodynamic Properties of Biochemical Substances

This review includes several tables: (1) Selected values of thermodynamic properties $\left(\Delta H_{\mathrm{f}}{ }^{\circ}, \Delta G_{\mathrm{f}}{ }^{\circ}, S^{\circ}\right.$, and $C_{\mathrm{p}}{ }^{\circ}$ ) for about 120 important biochemical species or compounds;

(2) Enthalpies and Gibbs energies of formation of adenosine phosphoric acid species relative to $\mathrm{H}_{2} \mathrm{ADP} \mathrm{P}^{1-}$ at $25^{\circ} \mathrm{C}$; (3) $\Delta H^{\circ}$ and $\Delta G^{\circ}$ for six important biochemical processes; and

(4) Partial molal properties $\left(\bar{L}_{2}, \bar{L}_{1}, \bar{C}_{2}\right.$, and $\left.\bar{C}_{1}\right)$ of aqueous glucose, glycerol, glycine, and urea at $25{ }^{\circ} \mathrm{C}$.

S. Ono and $\mathrm{K}$. Takahashi

Chemical Structure and Reactions of Carbohydrates

This article has a table of enthalpies of isomerization of eleven carbohydrates and a table giving enthalpies of hydrolysis of aqueous $\alpha-1,4$ and $\alpha-1,6$ glucosidic linkages in several glucosides at $25^{\circ} \mathrm{C}$.

T. Ackermann

Physical States of Biomolecules: Calorimetric Study of Helix-Random Coil Transitions in Solution

There is a tabulation of calorimetrically determined enthalpy values accompanying conformational changes of macromolecules in solution ( 26 references).

H. D. Brown

Calorimetry of Enzyme-Catalyzed Reactions

Tabulated are calorimetric enthalpy values for enzyme catalyzed systems ( 21 references). 
A Compilation of Selected Thermodynamic and Transport Properties of Binary Electrolytes in Aqueous Solution

(U. S. Atomic Energy Commission Report UCRL-17767 (1968))

Data from the literature on the properties of sixty-one common binary inorganic electrolytes at various temperatures are tabulated with appropriate references. The properties include the density, viscosity, transference number, diffusion coefficient, and the activity coefficient.

$$
* * * * * * * * * *
$$

12. Charlot, G.

Selected Constants - Oxidation-Reduction Potentials of Inorganic Substances in Aqueous Solution

(Butterworths, London, 1971)

This reference work, prepared under the auspices of the IUPAC, contains selected values of electrochemical potentials relative to the assigned zero value of the standard hydrogen electrode. Entries are given for about 350 inorganic systems. The literature coverage is through 1967.

$* * * * * * * * * * *$

13. Christensen, J. J., and Izatt, R. M.

Handbook of Metal Ligand Heats and Related Thermodynamic Quantities (second edition)

(Marcel Dekker, Inc., New York, 1975)

This handbook gives tabulated values of thermodynamic functions in aqueous solution. Enthalpies are given for equilibria involving metal ions and ligands, together with the related thermodynamic quantities $\log K, \Delta S$, and $\Delta C$, where available. The body of the book consists of a table (414 pp.) in which are summarized the published literature values up to 1974 , classified according to ligand. In addition, the appropriate reaction, the temperature, the method, and conditions of measurement of $\Delta H$ are given. Both inorganic and organic ligands, and complexes of about seventy metallic elements are given. A seven page guide to the use of the table and indexes is given. The table is indexed by author, by ligand formula, and by metal. An index of synonyms and a chronological list of references are also given.

$* * * * * * * * * *$

14. Christensen, J. J., Eatough, D. J., and Izatt, R. M. I, II

The Synthesis and Ion Binding of Synthetic Multidentate Macrocyclic Compounds

Chemica1 Reviews, 74, 351 (1974)

This review article contains, in addition to a discussion on the synthesis, kinetic, and structural parameters, a referenced compilation of $\log K, \Delta H, \Delta S$, and $\triangle C \mathrm{p}$ data for the interaction of inorganic cations with synthetic multidentate macrocyclic compounds. Each entry in the table of thermodynamic data includes the temperature, ionic strength, solvent system, and method of measurement used in obtaining the data. 
15. Clark, W. M.

Oxidation-Reduction Potentials of Organic Systems

I, II

(The Williams and Wilkins Company, Baltimore, 1960)

This 584 page monograph contains a comprehensive discussion on the determination of the electrochemical potentials of organic systems with emphasis both on theory and experimental practice. Included are approximately 100 tables of critically evaluated oxidation and reduction potentials for organic and biochemical systems thru about 1960 . Included are the quinones, phenols, anilines, porphyrins, nicotinamide-adenine dinucleotide, and nicotinamideadenine dinucleotide phosphate systems, and several others. The author has, in most cases, specified the conditions to which the data refer.

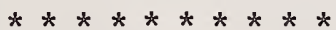

16. CODATA Recommended Key Values for Thermodynamics 1975

III, II

(CODATA Bulletin No. 17 (1976) and Tentative Set of Key Values for. Thermodynamics:

Part V, CODATA Special Report 3 , September 1975)

These are reports by the CODATA (Committee on Data for Science and Technology of the International Council of Scientific Unions) Task Group on Key Values for Thermodynamics in which are presented recommended values for the quantities $\Delta H_{\mathrm{f}}{ }^{\circ}(298.15 \mathrm{~K}), S^{\circ}$. $(298.15 \mathrm{~K})$, and $H^{\circ}(298.15 \mathrm{~K})-H^{\circ}(0 \mathrm{~K})$ for 102 of the thermochemically more important elements and compounds, including some aqueous species. These bulletins supersede earlier CODATA reports of this group. It should be noted that the recommended values are not fully consistent with any previously published thermodynamic tables, but are intended to form the basis of future generations of compilations (also see annotation on compilation by Parker, Wagman, and Garvin).

$* * * * * * * * * * *$

17. Coetzee, J. F., and Ritchie, C. D. (editors)

II, I

Solute-Solvent Interactions

(Marcel-Dekker, New York and London, 1969).

This book contains three chapters that are relevant to this bibliography. They are:

(1) Larson, J. W., and Hepler, L. G., "Heats and Entropies of Ionization". This chapter is a detailed review and evaluation of the enthalpies, Gibbs energies, entropies, and heat capacity changes accompanying ionization of organic acids. Included are eleven tables of data on various types of acids, including the carboxylic acids, phenols, anilinium ions, ammonium ions, the amino acids, barbituric acids, and several inorganic acids. The authors also discuss the interpretation of the data in terms of molecular considerations. The tabulated data refer to $25{ }^{\circ} \mathrm{C}$ and standard state conditions. There are 224 references.

(2) Arnett, E. M., and McKelvey, D. R., "Solvent Isotope Effect on Thermodynamics of Nonreacting Solutes". This is a general and extensive review dealing with differences in thermodynamic properties between light and heavy water systems. The properties dealt with include Gibbs energies and enthalpies of transfer and solubilities; systems for which data are tabulated include the more common inorganic electrolytes and ions, alcohols, amides, amino acids, and several non-electrolytes.

(3) Laughton, P. M., and Robertson, R. E., "Solvent Isotope Effects for Equilibria and Reactions". Included in this review are tabulated values giving differences in $\mathrm{p} K$ values for weak acids in light and heavy water. 
This monograph is a comprehensive ( $359 \mathrm{pp}$. ) collection of data on various aspects of pure and applied electrochemistry, relating to organic and inorganic substances, both solid and in solution. Data are presented in tabular form, in ten chapters, introduced with references to data sources and explanations of approach. Physical properties include densities and vapor pressures of various aqueous solutions, dielectric constants, dipole moments, and other properties. Relative partial molal enthalpies and activity and osmotic coefficients, conductance values, ionic mobilities, transference numbers and diffusion coefficients are tabulated. There is a chapter on dissociation constants, solubilities, and buffer solutions. The chapter on properties of electric double layers contains tables of electrokinetic potentials and properties of various interfaces including ones of such biological interest as the mammalian red blood cell. The biologist would also find relevant the section on transport and general properties of colloids and macromolecular electrolytes, including extensive tables of mobilities for such compounds as hemoglobins, serum albumins, and red blood cells, among others. Electrode chemistry tables include a compilation of data on reversible electrode processes: liquid junction potentials, half-cell potentials, and electrochemical equivalents for certain elements. A chapter on electrode kinetics gives a critical selection of the available determinations of the parameters of a number of electrode reactions.

$\star \star \star * * \star * * * * * *$

19. Covington, A. K.

III, I

Electrolyte Solutions Bulletin

(University of Newcastle Upon Tyne, 1971 to present)

This is a current awareness bulletin that provides titles and references of "recent papers covering all aspects of the physical chemistry and structure of electrolyte solutions, the methods used in these studies including spectroscopy, equilibrium (but not kinetic processes), electrode systems, $\mathrm{pH}$, ion selective and reference electrodes."

$* * \star * * * * * * *$

20. Cox, J. D., and Pilcher, G.

Thermochemistry of Organic and Organometallic Compounds

II, III

(Academic Press, London, New York, 1970)

This monograph is a critical compilation of thermochemical data for the title field published since 1930. The enthalpies of formation of some 3000 substances are listed, with estimates of error. Where enthalpies of vaporization are known or can be reliably estimated these are listed and in these cases the enthalpies of formation of both gaseous and condensed phases are given. Extensive introductory material presents experimental procedures for reduction of experimental data of the type found in the book. Applications of thermochemical data are given, and there is a section on methods of estimating enthalpies of formation of organic compounds. 
21. Domalski, E. S.

II, III

Selected Values of Heats of Combustion and Heats of Formation of Organic Compounds

Containing the Elements $\mathrm{C}, \mathrm{H}, \mathrm{N}, \mathrm{O}, \mathrm{P}$, and $\mathrm{S}$

Journal of Physical and Chemical Reference Data 1, 221-277 (1972)

Selected values of the enthalpies of combustion and enthalpies of formation of 719 organic compounds are reported. The selected values are augmented by commentary and original source references. The Wiswesser Line Notation is also given for each compound. The methods used in updating older work are described.

$* * * * * * * * * *$

22. Dorsey, N. E.

Properties of Ordinary Water-Substance

(Reinhold Publishing Corporation, New York, 1940)

This classic book is an exhaustive and critical compilation of the physical properties of water as reported in the literature through the year 1938. Essentially every physical property of pure water is covered. Although there is little emphasis on aqueous solutions, the solubilities and diffusion constants of selected gases in water are treated.

$* * * * * * * * * *$

23. Dymond, J. H., and Smith, E. B.

III, III

The Virial Coefficients of Gases

(Clarendon Press, Oxford, 1969)

This book is a critical compilation of the virial coefficients of about 280 gases at various temperatures. Included are references to the original sources as well as, in some cases, standard deviations and estimated inaccuracies for the data.

$* * * * * * * * * *$

24. Florkin, M., and Mason, H.

Comparative Biochemistry, Volume II. Free Energy and Biological Function

I, II

(Academic Press, New York, London, 1960)

This book contains several chapters dealing with the use of Gibbs energy data in biochemistry. The following chapters contain references to and/or tabulations of thermochemical data:

M. R. Atkinson and R. K. Morton, "Free Energy and Biosynthesis of Phosphates". This chapter contains a tabulation of Gibbs energies and equilibrium constants for various metabolic processes involving phosphates. The temperature, $\mathrm{pH}$, magnesium ion concentration, and appropriate literature references are given.

L. F. Leloir, C. E. Cardini, and E. Cabib, "Utilization of Free Energy for the Biosynthesis of Saccharides". Included in the discussion are some references to equilibrium data relevant to the biosynthesis of saccharides.

P. P. Cohen and G. W. Brown, Jr., "Ammonia Metabolism and Urea Biosynthesis". In their discussion of ammonia metabolism, the authors have used other compilations of thermodynamic data to compute Gibbs energy changes for these processes. 
25. Fox, D., Labes, M. M., and Weissberger, A. (editors)

II, III

Physics and Chemistry of the Organic Solid State

(Interscience Publishers (Wiley), 1963)

E. F. Westrum and J. P. McCullough

Chapter 1. The rmodynamics of Crystals

In addition to discussion of thermodynamic properties of organic substances and their measurement, this chapter (178 pp.) gives tables of entropy of fusion, and vapor pressures and a table of thermodynamic data sources for about 800 organic compounds ( 798 references).

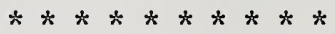

26. Franks, F. (editor)

Water- A Comprehensive Treatise (in five volumes)

II, I

(Plenum Press, New York and London, 1972 to 1975)

This treatise consists of forty-six chapters dealing with water and aqueous solutions. Although concerned with all aspects of water, several chapters contain extremely useful summaries of the rmodynamic data. Among these are:

Authors

F. Franks

Chapter

The Properties of Ice

Tabulated are the ionic equilibrium constant and transport properties of ice at $-10{ }^{\circ} \mathrm{C}$.

G. S. $\operatorname{Ke} 11$

Thermodynamic and Transport Properties of Fluid Mixtures

Included is the density of water as a function of temperature, the vapor pressure, specific heat, partial molal volume, critical properties, and viscosity of water.

K. Tödheide

Water at High Temperatures and Pressures

This chapter is an extensive tabulation of the high temperature properties of water. Included are the specific volume, fugacity, Gibbs energy and enthalpy of formation, entropy, viscosity, thermal conductivity, dielectric constant, and ion product of water.

F. Franks and D. S. Reid

Thermodynamic Properties

Given are $\Delta G^{\circ}, \Delta H^{\circ}, \Delta S^{\circ}$, and $\Delta C_{\mathrm{P}}^{\circ}$ for the solution of hydrocarbons, alcohols, and rare gases in water.

\section{H. L. Friedman and C. V. Krishnan}

The rmodynamics of Ionic Hydration

Tabulated are single-ion entropies of about 110 diatomic and polyatomic ions in water; Gibbs energies, enthalpies, and entropies of hydration of monatomic ions at $25{ }^{\circ} \mathrm{C}$; partial molal volumes of about 120 common ions at $25{ }^{\circ} \mathrm{C}$; ionic partial molal heat capacities of ions; Gibbs energies of transfer of inorganic electrolytes from $\mathrm{H}_{2} \mathrm{O}$ to $\mathrm{D}_{2} \mathrm{O}$; and calorimetrically determined enthalpjes of solution of salts in $\mathrm{H}_{2} \mathrm{O}$ and $\mathrm{D}_{2} \mathrm{O}$. 
26. (continued)

Authors

Chapter

D. Eagland

Nucleic Acids, Peptides, and Proteins

Thermodynamic parameters for coil $\rightarrow$ helix and homopolymer $\rightarrow$ coil helix transitions of amino acids in aqueous solution are tabulated.

H. L. Anderson and R. H. Wood Thermodynamics of Aqueous Mixed Electrolytes

Included are data on the enthalpies and excess Gibbs energies of mixing of about 24 mixed electrolyte systems in water.

$* * * * * * * * * *$

Gedansky, L. M., and Hepler, L. G. -- , see entry no. 96

$* * * * * * * * * *$

27. Glushko, V. P. (editor), Medvedev, V. A., Bergman, G. A., Gurvich, L. V., II, II and others

Thermal Constants of Substances (Volumes 1 to 7 )

(In Russian)

(VINITI, Moscow, 1965 to 1974 )

This extensive series represents many years of effort by numerous Russian thermodynamicists engaged in the critical evaluation of thermodynamic data. Included in the tables are carefully selected values of $\Delta H_{\mathrm{f}}{ }^{\circ}, \Delta G_{\mathrm{f}}{ }^{\circ}, S^{\circ}, H_{\mathrm{T}} \mathrm{H}_{\mathrm{O}}$, and $\mathrm{Cp}_{\mathrm{p}}$ at $298.15 \mathrm{~K}$ for the elements and their compounds including many aqueous species. Also given are dissociation energies of gases and enthalpies of phase changes. There are extensive references to the primary literature from which the tabulated values were obtained. In the volumes 1 isted, the elements, in the standard order of arrangement, through hafnium are covered. Carbon and its compounds are covered up to two carbons atom. The coverage and arrangements of substances is similar to that used in the NBS Technical Note 270 series (see Wagman, et al.)

$* * * * * * * * * *$

28. Goldberg, R. N., and Hepler, L. G. III, II Thermochemistry and Oxidation Potentials of the Platinum Group Metals and Their Compounds

Chemical Reviews, 68,229 (1968)

This article is a critical review and selection of thermochemical data for the platinum group metals and their compounds. Tabulated are selected values of $\Delta H_{\mathrm{f}}^{\circ}, \Delta G_{\mathrm{f}}^{\circ}, S^{\circ}$, and electrode potentials at $25^{\circ} \mathrm{C}$. There are 212 references to the primary literature.

$* * * * * * * * * *$

29. Hamer, W. J. (editor)

The Structure of Electrolytic Solutions

III, I

(John Wiley and Sons, Inc., New York, 1959)

This book contains several chapters relevant to this bibliography. They are:

Authors

Chapter

C. W. Davies

Incomplete Dissociation in Aqueous Salt Solutions

Tabulated are values of $-\log _{1} 0^{K}$ at $25^{\circ} \mathrm{C}$ for the pairing in aqueous soiution of elghteen common inorganic cations with thirty eight of the more common inorganic and organic anions. 
Authors

E. Lange

\section{Chapter}

Heats of Dilution of Dilute Solutions of Strong and Weak Electrolytes

This chapter contains a discussion of the theoretical interpretation and calculations of heats of dilution of electrolytes of various charge types with some information on non-electrolytes and weak electrolytes. Data from the literature are presented in graphical form. Included are data for eighteen inorganic electrolytes and seven inorganic non-electrolytes at $25^{\circ} \mathrm{C}$.

H. S. Harned

Diffusion and Activity Coefficients of Electrolytes in Dilute Aqueous Solutions

Tabulated are the activity coefficients, obtained from diffusion data, for twenty common aqueous electrolyte systems at $25{ }^{\circ} \mathrm{C}$.

F. H. Spedding and G. Atkinson

Properties of Rare Earth Salts in Electrolytic Solutions

Tabulated are the equivalent conductances, transference numbers, activity coefficients, densities and partial molal volumes, apparent molal compressibilities, heats of solution and dilution for the rare earth salts in aqueous solution.

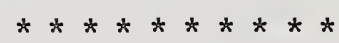

30. Hamer, W. J., and DeWane, H. J.

Electrolytic Conductance and the Conductances of the Halogen Acids in Water

III, I

(NSRDS-NBS 33, U. S. Government Printing Office, Washington, DC, 1970)

This monograph contains a detailed evaluation of equivalent conductance data for hydrofluoric, hydrochloric, hydrobromic, and hydroiodic acids in water over wide ranges of temperature and concentration.

$* \dot{*} * * * \frac{1}{*} * \frac{1}{*}$

31. Hamer, W. J., and Wu, Y. C.

The Activity Coefficients of Hydrofluoric Acid in Water from 0 to $35{ }^{\circ} \mathrm{C}$

III, I

Journal of Research of the National Bureau of Standards, 74A, 761 (1970)

This very detailed review on hydrofluoric acid contains critically evaluated data for the activity coefficient of $\mathrm{HF}$ as a function of molality and temperature $\left(0\right.$ to $35{ }^{\circ} \mathrm{C}$ ), equilibrium constants for the ionic association reactions characteristic of $\mathrm{HF}$, calculated $\mathrm{pH}$ values, and calculated concentrations of the pertinent ions.

$$
* \star * * * * * * * *
$$

32. Hamer, W. J., and Wu, Y. C.

III, I

Osmotic Coefficients and Mean Activity Coefficients of Uni-univalent Electrolytes in

Water at $25{ }^{\circ} \mathrm{C}$

Journal of Chemical Reference Data, 1,1047 (1972)

This evaluation gives values for the osmotic coefficients and mean activity coefficients of seventy-nine uni-univalent electrolytes in aqueous solution at $25^{\circ} \mathrm{C}$, with values 
expressed on the molality scale. The data from the literature were fitted, by statistical procedures, to equations which express the quantities as functions of electrolyte concentration. Literature references are given to fifty-one additional uni-univalent electrolytes.

$* * * * * * * * * * *$

33. Harned, H. S., and Owen, B. B.

The Physical Chemistry of Electrolytic Solutions (3rd Edition)

III, I

(Reinhold Publishing Corporation, New York, 1958)

This book (about $800 \mathrm{pp.}$ ) is a treatise on the physical chemistry of electrolytic solutions with coverage of both equilibrium and non-equilibrium properties. The book includes tables of values of the equivalent conductance, dissociation constants, transference numbers, diffusion coefficients, relative apparent molal heat contents, activity coefficients, $\mathrm{pH}$ values, densities, and activity coefficients for many of the more common inorganic and organic electrolyte solutions.

$$
* * * * * * * * * * *
$$

34. Harned, H. S., and Robinson, R. A. Multicomponent Electrolyte Solutions

(Pergammon Press, Oxford, 1968)

This monograph deals with the theoretical and experimental aspects of multicomponent and largely inorganic electrolyte solutions, with emphasis upon the measurement and interpretation of activity coefficients, heats of mixing, and volume changes accompanying mixing. There is a useful bibliography of activity coefficient data for mixed electrolyte systems. We note, for the reader's information, the following monographs published in the same series of books and which deal with electrolyte solution:

Author

E. A. Guggenheim and R. H. Stokes

R. H. Stokes and R. Mills

E. J. King

\section{Title of Volume}

Equilibrium Properties of Aqueous Solutions of Single Strong Electrolytes

Viscosity of Electrolytes and Related Properties

Acid-Base Equilibria

$* * * * * * * * * * *$

35. Hawkins, D. T.

A Bibliography on the Physical and Chemical Properties of Water

III, I

Journal of Solution Chemistry, 4, 621 (1975)

This bibliography consists of 1999 references to the literature that deal with physical properties of pure water or dilute aqueous solutions. The papers are arranged by category of properties. Categories include thermodynamic properties, transport data, densities, acoustical, electrical, magnetic, and radiation properties. The bibliography covers the years 1969 to 1974. An earlier bibliography covering the years 1957 to 1968 was also issued, but is now out-of-print. These two bibliographies have recently been combined and should be available from Plenum Press in 1976. 
36. Hepler, L. G., and Olofsson, G.

Mercury: Thermodynamic Properties, Chemical Equilibria, and Standard Potentials

Chemical Reviews, 75, 585 (1975)

This article is a critical review and selection of thermochemical data for mercury and about 130 of its compounds primarily inorganic but including many aqueous species. Tabulated are selected values of $\Delta G_{f}{ }^{\circ}, \Delta H_{f}{ }^{\circ}, S^{\circ}$, electrode potentials, and selected equilibrium constants at $25^{\circ} \mathrm{C}$. There are 251 references to the primary literature.

$* * * * * * * * * *$

37. Hill, J. 0., Worsley, I. G., and Hepler, L. G. Thermochemistry and Oxidation Potentials of Vanadium, Niobium, and Tantalum Chemical Reviews, 71, 127 (1971)

This article is a critical review and contains a careful selection of thermochemical data for vanadium, niobium, and tantalum and about 110 of their compounds, including some aqueous species. Tabulated are selected values of $\Delta G_{f}{ }^{\circ}, \Delta H_{f}{ }^{\circ}, S^{\circ}$, and electrode potentials at $25{ }^{\circ} \mathrm{C}$. There are 121 references to the primary literature.

$$
* * * * * * * * *
$$

Ingraham, L. L., and Pardee, A. B. -- see entry no. 97

$$
\text { *ै* } * * * * * * * *
$$

38. Izatt, R. M., Christensen, J. J., and Rytting, J. H.

I, II

Sites and Thermodynamic Quantities Associated with Proton and Metal Ion Interaction with Ribonucleic Acid, Deoxyribonucleic Acid, and Their Constituent Bases, Nucleosides, and Nucleotides

Chemical Reviews, 71, 439 (1971)

This review contains twenty-three journal pages of tables of thermodynamic data ( $\log K, \Delta H$, $\Delta S$, and $\Delta C_{\mathrm{P}}$ ) pertinent to the interaction of protons and metal ions with the nucleic acids and their molecular components together with the methods and experimental conditions ( $\mathrm{pH}$, temperature, ionic strength) used in their determination. There are 229 references to articles in the literature.

$\star \star * * * \star * \star \star \star * *$

39. Janz, G. J.

Thermodynamic Properties of Organic Compounds

Estimation Methods, Principles, and Practice (revised edition)

(Academic Press, Inc., New York, London, 1967)

This well established monograph discusses computation of thermodynamic properties such as heat capacities, entropies, enthalpies and Gibbs energies by statistical mechanical methods, by methods of structural similarity, by methods of group contributions, by methods of group equations, and by methods of generalized vibrational assignments. The chemical properties: enthalpy of formation, and enthalpy of combustion are treated in terms of bond energies and group increments. Some 78 tables are given of increments, group contributions, and bond contributions as specifically needed for estimation of particular properties. 
40. Janz, G. J., and Tomkins, R. P. T.

Non-Aqueous Electrolytes Handbook (in two volumes)

(Academic Press, New York, 1972)

These volumes contain extensive tabulations of physical data pertinent to non-aqueous solvents, both single solvent and mixed solvent systems. The properties that are tabulated include melting point, boiling point, dielectric constant, viscosity, specific conductance, density, transference number, solubility, enthalpy of solution and dilution, $\mathrm{E}^{\circ}$ values for electrochemical cells, vapor pressure, polarographic data, ligand exchange rate, and spectroscopic data. The vast majority of the approximately 300 solvent systems dealt with are organic. There is a substance-property index, and sources of data are referenced.

$* * * * * * * * * *$

Jazimirski (Yatsimiraskii), K. B. -- see entry no. 98

$* * * * * * * * *$

41. Jordan, T. E.

Vapor Pressure of Organic Compounds

III, III

(Interscience Publishers, Inc., New York, 1954)

This is a comprehensive compilation (266 pages) of vapor pressure data for organic compounds. Included are tables on the hydrocarbons, alcohols, aldehydes, esters, ketones, acids, phenols, and metal organic compounds. Data for each compound are shown in graphical form, i.e. vapor pressure as a function of temperature. References to the data sources in the literature are given.

$* * * * * * * * * * *$

42. Joshi, R. M., and Zwolinski, B. J.

Vinyl Polymerization, Volume 1, Part I, edited by G. E. Ham

II, III

(Marcel Dekker, Inc., New York, 1967)

Chapter 8: Heats of Polymerization and their Structural and Mechanistic Implications

The authors discuss experimental methods used to measure and derive enthalpies of polymerization. A listing of experimental data on enthalpies of polymerization is provided for 81 organic polymerization reactions. Other tables give enthalpies of formation, enthalpies of vaporization, entropies, Gibbs energies, equilibrium constants, rate constants and activation energies at $25{ }^{\circ} \mathrm{C}$ for a variety of polymerization processes. A discussion of the structural influence upon the enthalpy of polymerization is also given. At the end of the chapter, 164 references are cited.

$* * * * * * * * * *$

43. Karapet'yants, M. Kh., and Karapet'yants, M. L.

Thermodynamic Constants of Inorganic and Organic Compounds

II, II

(Ann Arbor Humphrey Science Publishers, Ann Arbor and London, 1970)

translated from the Russian; Osnovnye Termodinamicheskie Konstanty Neorganicheskikh $i$

Organicheskikh Veshchestv (Izdatel'stvo "Khimiya", Moskva, 1968)

This book is a compilation of $\Delta H_{\mathrm{f}}{ }^{\circ}, \Delta G_{\mathrm{f}}{ }^{\circ}, S^{\circ}$, and $C \mathrm{p}$ values at $298.15 \mathrm{~K}$ for about 4000 substances in the condensed and gaseous phases, and in aqueous solution. Covered are not only the inorganic elements and their compounds, but also data for the organic compounds through 34 carbon atoms. The authors point out that their tabulated values do not always form a self-consistent system of thermodynamic data. There are 2733 references. 
This monograph, published under the auspices of the American Chemical Society, has in its Appendix a useful compilation of the physical properties of aqueous sodium chloride solutions. Included are essentially all of the measured equilibrium and transport properties of this system at various temperatures and pressures. The data are well referenced.

45. Kazavchinskii, Ya. Z., Kessel'man, P. M., Kirillin, V. A.,

Riukin, S., Sheindlin, A. E., Shpil'rain, E. E., Sychev, V. V., and Timrot, D. L. (edited by V. A. Kiri11in)

Heavy Water-Thermophysical Properties

(U. S. Department of Commerce, National Technical Information Service, Springfield, VA 1971)

Translated from the Russian Tyazhelaya voda. Teplofizicheskie svoistva (Gosudarstvennoe energeticheskoe izdatel'stvo, Moskva-Leningrad, 1963)

This treatise is an exhaustive compilation of physical data on heavy water (deuterium oxide). Some of the more relevant properties that are covered include densities, critical constants, vapor pressures, enthalpies of transition, viscosity, and thermal conductivity, equation of state, and tables of thermodynamic properties as functions of temperature and pressure.

$* * * * * * * * * *$

Keevan, H. J., Keyes, F. G., Hil1, P. G., and Moore, J. G. -- see entry no. 99

$* * * * * * * * * *$

46. Kortum, G., Voge1, W., and Andrussow, K.

II, I

Dissociation Constants of Organic Acids in Aqueous Solution

(Butterworths, London, 1961)

This book is a compilation of 1056 dissociation constants of organic acids in aqueous solution, presented in tabular form. Introductory and explanatory remarks are in both German and English. Remarks in the Table are in German. Part I is a critical discussion of techniques for measurements of dissociation constants by conductance, electrometric, catalytic and optical methods. Each method is classified and coded in Part II, on use of the table, where methods of calculation and corrections for solvent and for hydrolysis of salts in conductivity measurements are also coded, for reference in the table. The Table itself is arranged by acid class including: aliphatic and alicyclic carboxylic acids, aromatic carboxylic acids, phenolic acids, and other acids and special classes. The Table gives the name, chemical formula, and thermodynamic dissociation constant $K$ of each acid, the temperature $\left({ }^{\circ} \mathrm{C}\right)$ of measurement, the range of concentration over which the measurements were made, code for the method of measurement, calculation procedure and any corrections made, a critical evaluation of the quality of the measurement, and the source reference. All data were drawn from the literature, covering the period between 1927 and 1956, and are referenced in a classified reference list. A compound index is provided.

47. Krebs, H. A., and Kornberg, H. L., with appendix by K. Burton I, II Energy Transformations in Living Matter

(Springer-Verlag, Berlin, 1957)

The main part of this monograph surveys the various biochemical pathways by which 11 ing systems utilize energy. In the Appendix are (1) Tables of Gibbs energies of formation of ninety-eight compounds of biological importance, (2) Gibbs energies and electrochemical potentials of important biological oxidation-reduction reactions, and ( 3 ) Gibbs energy changes 


\section{7. (continued)}

accompanying the processes of glycolysis and alcoholic fermentation, the tricarboxylic acid cycle, and hydrolysis. The source of data is given for each entry.

48. Latimer, W. M.

II, I

The Oxidation States of the Elements and their Potentials in Aqueous Solution (second edition)

(Prentice-Hal1, Inc., Englewood Cliffs, New Jersey, 1959)

This book contains extensive tables of $\Delta G_{f}{ }^{\circ}, \Delta H_{f}{ }^{\circ}$, and $S^{\circ}$ values for the elements and their compounds as well as electrode potential diagrams calculated from the tabulated $\Delta G_{\mathrm{f}}{ }^{\circ}$ values, from other measurements, and estimates when appropriate. Much of the tabulated data were taken from National Bureau of Standards Circular 500 (see entry no. 73). The appendixes include activity coefficient data for 77 strong electrolytes and a discussion of methods whereby entropies may be estimated.

49. Lewis, G. N., and Randal1, M.

(revised by Pitzer, K. S., and Brewer, L.)

Thermodynamics

(McGraw-Hill Book Company, New York, 1961)

This standard textbook on thermodynamics contains an Appendix of selected data for aqueous electrolyte solutions. Compiled are activity coefficients, relative partial molal enthalpies, and relative partial molal heat capacities for about 70 of the most common electrolytes in aqueous solution at $25{ }^{\circ} \mathrm{C}$.

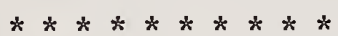

50. Linke, W. F, and Seidell, A.

Solubilities: Inorganic and Metal-Organic Compounds--A Compilation of Solubility Data from the Periodical Literature. Volume I: A-Ir, Volume II: K-Z

(Volume I: D. Van Nostrand Co., Princeton, New Jersey, 1958; Volume II: American Chemical Society, Washington, DC, 1965)

These two volumes (total of 3401 pages) are comprehensive compilations of mostly unevaluated solubility data for inorganic and metal-inorganic compounds. Both aqueous and non-aqueous solvent systems are included. References are given to the data sources.

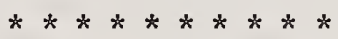


51. Long, C. (editor)

Biochemists Handbook

(D. Van Nostrand Co., Princeton, New Jersey, 1961)

This reference book contains several tables of thermochemical data:

S. P. Datta and A. K. Grzybowski

$\mathrm{pH}$ and Acid-Base Equilibria

This chapter contains a discussion of $\mathrm{pH}$ scales and the electrometric measurement of $\mathrm{pH}$, tables of assigned $\mathrm{pH}$ values for various buffered solutions, and tables (about 600 entries) of thermodynamic acid dissociation constants of weak organic acids (some as a function of temperature).

K. Burton

Free Energy Data and Oxidation-Reduction Potentials

This chapter contains some revisions and additions to Burton's earlier tables (see, in this bibliography, the book by Krebs and Kornberg).

$$
\dot{*} * \dot{*} * \dot{*} * \dot{*} * *
$$

52. Martell, A. E., and Smith R. M.

Critical Stability Constants. Volume I: Amino Acids

I, II

(Plenun Press, New York, 1974)

and

Smith, R. M., and Marte1l, A. E.

Critical Stability Constants. Volume II: Amines

(Plenum Press, New York, 1975)

Volume I contains selected values of $\log K, \Delta H$, and $\Delta S$ at $25{ }^{\circ} \mathrm{C}$ for the interaction of inorganic metal and hydrogen ions with several classes of organic ligands. The organic ligands dealt with are the aminocarboxylic acids, iminodiacetic acid and its derivatives, peptides, aniline carboxylic acids, pyridine carboxylic acids, peptides, and several other miscellaneous ligands. The arrangment of data is similar to that of the work of Sillen, Martell, Hogfeldt, and Smith except that the data are critically selected from the literature rather than being simply compiled. Each selected datum contains a reference to the primary literature. This 469 page volume contains a ligand formula and name index.

Volume II (415 pages) is similar in arrangement to Volume I. The organic ligands dealt with are the aliphatic, secondary, and tertiary amines, azoles, azines, and the amino phosphorous acids .

$* \star \star \star \star * * * * * \frac{1}{*} *$

53. Meites, L. (editor)

Handbook of Analytical Chemistry

(McGraw-Hill Book Co., New York, 1963)

This treatise on analytical chemistry contains several useful tabulations of thermochemical data. Some of these tabulations are taken directly from other sources cited in this bibliography and are not included below:

Author (s)

V. E. Bowers and R. G. Bates

\section{Title of Section}

Equilibrium Constants of Proton-transfer Reactions in Water

Tabulated are $\mathrm{pK}$ values at 15,25 , and $35{ }^{\circ} \mathrm{C}$ for about 200 organic and inorganic acids; no literature references are given. 
53. (continued)

L. Meites

Formal Equilibrium Constants of Proton-transfer Reactions at Finite Ionic Strength

This section contains a tabulation of $\mathrm{pK}$ values at $25{ }^{\circ} \mathrm{C}$ for a selected series of about 150 acids, and bases. These data were taken from Bjerrum, Schwarzenbach, and Sillen, "Stability Constants of Metal Complexes", part I, Chemical Society, London, 1957. Also given are tables of acid dissociation data pertinent to ethanol-water and methanol-water mixtures.

D. A. Aikens and C. N. Reilley

Formation Constants of Metal Complexes

Tabulated are $\log K$ values for the binding of the more common inorganic metal ions to 55 ligands. $\Delta H$ and $\Delta S$ values are also given for four ligands. Literature references are given.

$\star \star \star \star \star * * * * * * *$

54. Merrill, A. L., and Watt, B. K.

Energy Value of Foods; Basis and Derivation

I, III

Agricul ture Handbook No. 74, 1955

Watt, B. K., and Merill, A. L.

Composition of Foods; Raw, Processed, Prepared

Agriculture Handbook No. 8, revised, 1963

(U. S. Government Printing office, Washington, DC 20402)

This pair of monographs provides numerous composition and energy values for food and foodstuff ingredients. It should be noted, of course, that the Calorie used in food energy values is one kilocalorie $(4 \mathrm{~kJ})$ as used in thermochemistry. In Agriculture Handbook No. 74, Part I gives a discussion of the sources of food energy in terms of organic compound class, and of the experimental determination of enthalpies of combustion. Parts II, III, and IV apply the data to physiological processes. An appendix gives composition and enthalpy of combustion of foods. Tables 1-5 and table 24 give enthalpies of combustion of specific food items or component substances. Care should be used in taking values from the numberous tables, as correction factors have sometimes been applied to adjust for physiological processes. These adjustments are indicated by footnotes. In Agriculture Handbook No. 8, Appendix A is of particular interest as it gives notes on energy values and nutrients, including (adjusted) enthalpies of combustion of many foods and food ingredients.

$* * * * * * * * * *$

55. Miller, D. G.

III, I

Application of Irreversible Thermodynamics to Electrolyte Solutions. I. Determination of Ionic Transport Coefficients $\ell_{i j}$ for Isothermal Vectcr Transport Processes in Binary Electrolyte Systems. II. Ionic Coefficients $\ell_{i j}$ for Isothermal Vector Transport Processes in Ternary Systems.

Journal of Physical Chemistry, 70, 2639 (1966); 71, 616 (1967)

These papers derive equations relating fundamental isothermal transport coefficients ( ${ }_{i j}$ 's) to experimentally measurable quantities for electrolytes in a neutral solvent. $\ell_{i j}$ 's for the most common aqueous ionic solutions are calculated from critically reviewed data. 
56. Millero, F. J.

The Partial Molal Volumes of Electrolytes in Aqueous Solutions. Compilation

of the Partial Molal Volumes of Electrolytes at Infinite Dilution, $\overline{\mathrm{V}}^{\circ}$ and the Apparent Molal Volume Concentration Dependence Constants, $\mathrm{S}_{\mathrm{v}}^{*}$ and $\mathrm{b}_{\mathrm{v}}$, at Various Temperatures

Water and Aqueous Solutions, R. A. Horne (editor)

(Wiley-Interscience, New York, 1972)

This chapter is concerned with the measurement and interpretation of partial

molal volumes and their concentration and temperature dependences. Included are tables of the partial molal volumes of the common inorganic and organic electrolytes (about 200 systems) as well as values of the partial molal volumes of the more common inorganic and organic ions (about 100 species). The data refer to temperatures from 0 to $200{ }^{\circ} \mathrm{C}$.

$* * * * * * * * * *$

57. Millero, F. J.

The Molal Volumes of Electrolytes

Chemical Reviews, 71, 147 (1971)

This is a detailed and thorough review article dealing with molal volumes of electrolytes in water. Included is a history and discussion of theoretical developments associated with molal volumes. Tabulated are the partial molal volumes of the common (about 50) inorganic and organic ions in water at temperatures ranging from zero to $200{ }^{\circ} \mathrm{C}$. There is also given partial molal volume data for non-aqueous systems. There are 366 references to the literature. Also see entry no. 56 above.

$* * * * * * * * * * *$

58. Mishchenko, K. P., and Poltoratzkii, G. M.

II, I

Aspects of the Thermodynamics and Structure of Aqueous and Non-Aqueous Electrolyte Solutions

(Izd. "Khimia", Leningrad, 1968) (In Russian)

This 350 page monograph contains extensive discussions and correlations (theoretical and empirical) of existing experimental data on enthalpies, Gibbs energies, and entropies, of solution and ionization of inorganic acids, bases, and salts in water and selected organic solvents. Heat capacities, enthalpies, Gibbs energies, and entropies of the substances and their ions in solution are also discussed. Extensive use is made of diagrams relating observed properties to periodic groupings of the elements. The monograph contains numerous small tables of properties of limited groups of substances. A summary compilation of selected values of thermodynamic properties occupies 43 pages, giving $\Delta H_{f}{ }^{\circ}, \Delta G_{f}{ }^{\circ}, S$ and $C p$ of pure and dissolved inorganic substances in their standard state at $25^{\circ} \mathrm{C}$, selected enthalpies of solution at $25{ }^{\circ} \mathrm{C}$, enthalpies of dilution of common acids, bases, and salts at $25{ }^{\circ} \mathrm{C}$, and heat contents and partial molar heat capacities for selected salts vs. concentration and temperature in water, methano1, ethanol, and a few other organic solvents.

$\star * * * * * * * * * *$

Naoomov, G. B., Rhizenko, B. N., and Kodakovski, I. L. -- see entry no. 100 
59. Parker, V. B.

Thermal Properties of Aqueous Uni-univalent Electrolytes

III, I

(NSRDS NBS 2, U. S. Government Printing Office, 1965)

This short ( $41 \mathrm{pp.}$ ) monograph is a review of the heat-capacity, enthalpy-of-solution, and enthalpy-of-dilution data on simple 1-1 electrolytes, organic and inorganic, in dilute aqueous solutions. From the critical analysis of this data, tables of selected "best" values of apparent heat capacities, and enthalpies of dilution are given, as well as selected values of the enthalpies of solution to the infinitely dilute solution. Also included is a review of data on the enthalpies of neutralization of monobasic acids which has led to a selected "best" value for the enthalpy of ionization of water. Data on each property are introduced with a discussion of methods employed in reducing the data to a standard form and are listed by compound, in the order: acids, ammonium and amine salts, silver salts, and salts of the alkali metals. For each compound are listed the various investigations, with the temperature and range of concentrations measured. Graphs of molal heat capacity and molal enthalpy as functions of concentration are also included, for aqueous solutions of many of the compounds discussed. In addition, there is an abbreviated listing, by compound, of review and compilation papers on the thermal properties of the aqueous uni-univalent electrolytes. These and other references are also listed alphabetically in a separate reference section with 652 entries. The chosen "best" values for each parameter and compound are arranged in a series of 21 tables for $t=25{ }^{\circ} \mathrm{C}$.

$* * * * * * * * * *$

60. Parker, V. B., Wagman, D. D., and Garvin, D.

Selected Thermochemical Data Compatible with the CODATA Recommendations

III, II

(National Bureau of Standards Report No. 75-968, Washington, DC, 1976)

Selected thermochemical properties, $\Delta G_{\mathrm{f}}{ }^{\circ}, \Delta H_{\mathrm{f}}{ }^{\circ}, S^{\circ}, C_{\mathrm{p}}^{\circ}$ (all at $298.15 \mathrm{~K}$ ), $\Delta H_{\mathrm{f}}{ }^{\circ}(0 \mathrm{~K}$ ), and $H(298 \mathrm{~K})-H(0 \mathrm{~K})$, are given for 384 substances (almost entirely inorganic) including many of the more commonly encountered aqueous species. The selected values are intended to be compatible with the current CODATA recommendations on key values for thermodynamics. (see CODATA Recommended Key Values for Thermodynamics).

$* * * * * * * * * *$

61. Parsons, R.

Handbook of Electrochemical Constants

III, I

(Academic Press, New York, 1959)

This handbook contains extensive tables of data for the more common inorganic and organic aqueous electrolyte solutions. Properties covered include dielectric constants, activity coefficients, relative partial molal enthalpies, equilibrium constants, solubility products, conductivities, electrochemical potentials, Gibbs energies and enthalpies of formation, entropies, heat capacities, viscosities, and diffusion coefficients. Unfortunately, only a few of the tables contain references to the sources of the data.

$* * * * * * * * * * *$

62. Pauling, L.

The Nature of the Chemical Bond (third edition)

III, III

(Cornell University Press, Ithaca, New York, 1960)

This well established monograph provides general information about the nature of chemical bonding in (principally) inorganic compounds which is fundamentally very important for the estimation of enthalpies of formation, but not always easily applied. 
These thermochemical tables consist of enthalpies of formation at $298.15 \mathrm{~K}$ calculated from thermochemical data networks. Included are appropriate references to the literature and estimated errors in the enthalpies of formation. An interesting and important feature of this scheme is that the tables can be readily updated by computer. These tables contain a substantial amount of data for aqueous species. To date, the following tables have appeared:

Element

Halogen Compounds (Fluorine, Chlorine, Bromine, Iodine)

Nitrogen

Phosphorous

Silicon

Chromium, Molybdenum and Tungsten

\section{Author (s)}

J. D. Cox

G. Pilcher

A. J. Head

J. B. Pedley and

B. S. Iseard

D. S. Barnes
Year

1972

1972

1972

$* * * * * * * * * * *$

64. Perrin, D. D.

Dissociation Constants of Inorganic Acids and Bases in Aqueous Solution

II, II (Butterworths, London, 1969)

This short (163 pp.) monograph is a compilation of dissociation constants of 217 inorganic acids and bases. The classes of compounds include not only conventional acids and bases, but also hydrated metal ions and free radicals, such as hydroxyl, the only criterion being gain or loss of a proton or hydroxyl ion. The data are organized into a single table listing 217 compounds, preceded by a brief introduction to the use of the table, and a section on methods of measurement and calculation. The methods are classified as conductometric, electrometric, optical, or other. Elements and compounds are listed in decreasing extent of protonation. $\mathrm{p} K$ values are, wherever possible, obtained by extrapolation to ionic strength $I=0$. The table also gives the temperature of each measurement, remarks as to ionic strength, concentration, and any other factors relating to $\mathrm{p} K$, coded references to method of measurement, the procedure used in evaluating the constants and any corrections taken into consideration, and the literature references. There are approximately 1100 references listed alphabetically by author.

$$
* * * * * * * * * *
$$

65. Perrin, D. D.

Dissociation Constants of Organic Bases in Aqueous Solution

II, II

(Butterworths, London, 1965)

Published in the same series as the book by Kortum, Vogel, and Andrussow, this book tabulates values of dissociation constants for organic bases in aqueous solution. The bases are arranged under the headings aliphatic, alicyclic, aromatic, heterocyclic, natural products, dyes and indicators, substances lacking a basic nitrogen atom, and miscellaneous. Accompanying the data entry for each base is the temperature, method of measurement, formula, assessment of the measurement, and the appropriate reference. There are 3790 data entries in this book. 
66. Phillips, R.

Adenosine and the Adenine Nucleotides. Ionization, Metal Complex Formation, and

Conformation in Solution

Chemical Reviews, 66, 501 (1966)

This article is a detailed review of the thermodynamics, kinetics, and structural characteristics of adenosine and the adenine nucleotides in solution. Both $\log K$ and enthalpy data are tabulated for protonation and metal-ion binding reactions to adenosine and the adenine nucleotides. Included for the tabulated data are the ionic strength, temperature, supporting electrolyte, $\mathrm{pH}$, method of measurement, and references to the original data source.

$$
* * * * * * * * * *
$$

67. Phillips, R. C., George, P., and Rutman, R. J. Thermodynamic Data for the Hydrolysis of Adenosine Triphosphate as a Function of $\mathrm{pH}$, $\mathrm{Mg}^{2+}$ Ion Concentration, and Ionic Strength Journal of Biological Chemistry, 244, 3330 (1969)

This article deals with the computation of the Gibbs energy change for the hydrolysis of adenosine-5'-triphosphate to adenosine-5'-diphosphate as a function of magnesium ion concentration, $\mathrm{pH}$, and fonic strength. A critical evaluation of the existing data pertinent to this computation is included. References to 24 papers are given.

$* * * * * * * * * *$

68. Pourbaix, M. (and others)

Atlas of Electrochemical Equilibrium in Aqueous Solution

III, I

(Pergammon Press, Oxford, 1966)

This book contains tabulations of Gibbs energy of formation data for many of the principal compounds of the inorganic elements. Electrochemical potentials and their dependence on $\mathrm{pH}$, are calculated for many important couples. Much of the Gibbs energy data is taken from the evaluations and compilations of others.

$* * * * * * * * * * *$

69. Reid, R, C., and She rwood, T, K.

III, II

The Properties of Gases and Liquids, Their Estimation and Correlation (second edition) (McGraw-Hill Book Co., New York, 1966)

This lengthy monograph discusses various methods available for calculating or estimating properties of materials, and then provides recommendations for action with respect to each kind of property. Included in the book are procedures for making estimates of critical constants, normal boiling temperatures, Lennard-Jones potential parameters, compressibility factors and equations of state, liquid molal volumes and densities, and vapor pressures. Estimates of enthalpies of vaporization, of ideal-gas heat capacities, and of enthalpies and Gibbs energies of formation are treated. For real fluids variations of enthalpy, entropy, internal energy, and heat capacity with pressure are treated. Some methods are given for estimating the properties of fluid mixtures. Surface tension and the transport properties--viscosity, diffusion coefficient and thermal conductivity--are discussed. Numerous tables present comparisons of observed and calculated properties. 
70. Robinson, R. A., and Stokes, R. H.

Electrolyte Solutions. The Measurement and Interpretation of Conductance, Chemical Potential and Diffusion in Solution of Simple Electrolytes (second edition, revised) (Butterworths, London, 1965)

In this, the revised second edition of a monograph first published in 1955, the first part presents a fundamental discussion of aqueous organic and inorganic electrolyte solutions. Included is a discussion of ionizing solvents (i.e. water), electrolytic conductivities and transport numbers, the measurement and interpretation of chemical potentials; the theory of diffusion (emphasizing conductance and viscosity in concentrated solutions), and methods of measurement of diffusion coefficients. The final third of the text deals primarily with characteristics of specific electrolyte solutions, including weak and mixed electrolytes, and strnng acids, and includes an extensive (98 pp.) appendix with approximately 75 tables of osmotic and activity coefficients, standard cell potentials $\left(E^{\circ}\right)$ in various organic solvents, ionic radii, and ionization constants of organic acids in aqueous solution, and other information. The narrative is supplemented with graphs, tables, equations, and references.

***********

71. Rossini, F. D., Pitzer, K. S., Arnett, R. L., Brown, R. M., and

II, III

Pimente1, G. C.

Selected Values of Physical and Thermodynamic Properties of Hydrocarbons and Related Compounds

(Carnegie Press, Pittsburgh, Pennsylvania, 1953)

This monograph resulted from the work of American Petroleum Institute (API) Research Project 44. Values are given for 40-odd physical and thermodynamic properties of several hundred hydrocarbons in metric and U. S. Customary units. The data in most instances represent selected values from careful studies, many of which were done in connection with the same API Research Project. Experimental data are supplemented by theoretical calculations or empirical correlations. References to the source data and a bibliography are given. This is a revision of NBS Circular C461 (entry no. 72 below).

$* * * * * * * * * *$

72. Rossini, F. D., Pitzer, K. S., Taylor, W. J., Ebert, J. P. II, III

Kilpatrick, J. E., Beckett, C. W., Williams, M. D., and Werner, H. C.

Selected Values of Properties of Hydrocarbons

National Bureau of Stnadards Circular C461 (1947)

(U. S. Government Printing Office, Washington, DC)

This monograph was prepared as part of the work of the American Petroleum Institute (API) Research Project 44. Values are given for 36 physical and thermodynamic properties of several hundred hydrocarbons in metric and in U. S. Customary units. The data in most instances represent values found from careful studies, many of which were done in connection with the same API Research Project. Experimental data are supplemented by theoretical calculations or empirical correlations. References to the source data and a bibliography are given. Entry no. 71 above is a revision of this work. 
73. Rossini, F. D., Wagman, D. D., Evans, W. H., Levine, S., and

II, II

Jaffe, I.

Selected Values of Chemical Thermodynamic Properties

National Bureau of Standards Circular 500 (1952)

(U. S. Government Printing Office, Washington, DC 20402)

This was for many years the most comprehensive authoritative compilation of thermochemical data at 298.15 K for inorganic substances. All inorganic substances and organic substances containing two carbon atoms or fewer per molecule are included if thermodynamic data exist for calculating one of the properties tabulated. Properties tabulated in Part I are $\Delta H_{\mathrm{f}}^{\circ} 0, \Delta H_{\mathrm{f}}^{\circ} 298, \Delta G_{\mathrm{f}}{ }^{\circ} 298, \log K_{\mathrm{f}}, S^{\circ}{ }_{298}$, and $C_{\mathrm{p}}{ }^{\circ} 298$. Properties tabulated in Part II are temperature, pressure, enthalpy change, entropy change and heat capacity change for transition, fusion, and vaporization processes. The data from original sources were critically evaluated by competent thermochemists and

functions tabulated, maintaining internal consistency by the relationship:

$\Delta G_{\mathrm{f}}{ }^{\circ} 298=\Delta H_{\mathrm{f}}{ }^{\circ} 298-\mathrm{T} \Delta \mathrm{S}^{\circ} 298$. The sources of data for each data $i$ tem are listed and a bibliography is included. Some information in this book can still not be found readily elsewhere as the revision is not yet complete. Also, see Wagman, et al. in this

bibliography.

$* * * * * * * * * * *$

74. Schafer, D., and Lax, E. (editors)

II, III

Landol t-Börnstein

Zahlenwerte und Fuctionen aus Physik, Chemie, Astronomie, Geophysik, und Technik,

Sechste Auflage

Eigenschaften der Materie in Thren Aggregatzustanden

4 Teil, Kalorische Zustandsgrossen

(Springer-Verlag, Berlin, 1961) (in German)

This most recent issue of thermodynamic information of the Landolt-Bornstein series gives thermal properties: molar heat capacity, entropy, enthalpy, enthalpy of formation, Gibbs energy of formation, in the standard state, and enthalpies of phase changes for many organic and inorganic substances in SI units. The dependence of thermal functions and heat capacity upon temperature is given for many substances. Some other thermodynamic quantities are given. Extensive tables are given of group contributions to enthalpies of formation and the Gibbs energies of formation of organic substances (gases) in kcal mol-1 and $\mathrm{kJ} \mathrm{mol}^{-1}$. Many of the heat capacity data are presented in diagrams. This series also includes tables of freezing point depressions, conductivities, transference numbers, and densities for aqueous systems.

$* * * * * * * * * * *$

75. Sillen, L. G., Martell, A. E., Hogfeldt, E., and Smith, R. M.

II, I

Stability Constants of Metal Ion Complexes, Section I: Inorganic Ligands,

Section II: Organic Ligands (second edition)

(Special Publication No. 17, The Chemical Society, London, England, 1964 and

Supplement No. 1, Special Publication No. 25, 1971)

With the publication of this second edition of Stability Constants, the Chemical Society combined two previously separate volumes into one, two-part volume ( $745 \mathrm{pp}$.$) , the first$ covering constants of inorganic ligands, the second, organic ligands. Both sections include all data published up to the end of 1960 and some from 1961-63; the scope of the inorganic section has been extended to cover redox equilibria and the extraction of inorganic ligands into non-aqueous solvents. The data are organized into separate tables, each table summarizing the data for the association of one particular ligand with all the metallic lons which have been studied in conjunction with it. Method of measurement, composition, and temperature of the media to which the data refer, are given for each Iigand-metal pair. Acid dissociation constants of the ligands are recorded by including the hydrogen ion as one of the cations with which the ligands associate. Redox equilibria are represented by including the electron as a ligand, and hydrolysis of metallic ions is described by 
regarding the hydroxyl ion as one of the ligands.

The arrangement of material is now more uniform than in the two parts of the first edition, but there remain minor differences of presentation between the inorganic and the organic section. In the inorganic table, 80 ligands are ordered according to group in the periodic system; metal ions are arranged within each inorganic ligand table, in the same order. In the organic section, the ligands (1028) are in order of their empirical formulae, and the metallic ions in the alphabetical order of their international symbols. Methods of measurement are given, with 42 separate methods alphabetized and coded in the introduction; medium is usually aqueous. Equilibrium constants are given in both tables. The organic section includes consecutive or stepwise constants, $K$, whenever possible, and cumulative or gross constants, $\beta$, if they are the only quantities determined, or if the sequence of stepwise constants is incomplete. The inorganic table includes equilibrium constants for consecutive and cumulative reactions, solubility constants, acid constants and base constants. Certain special constants are also given; e.g. Kp - equilibria involving a gas. Both tables give enthalpy and entropy changes, and symbols relating to the references which are listed at the end of each table. Each of the metals, inorganic ligands and organic ligands are indexed alphabetically, with appropriate table number, at the end of the book.

The supplement to the second edition of "Stability Constants of Metal-Ion Complexes" is a review of pertinent literature published between the completion of the 1964 Tables and the end of 1968, including also some data published before the completion of the 1964 Tables, but omitted from them. In the organic part, a change of policy has been initiated; rather than being omitted, results seeming incomplete or of dubious validity are now included in the tables, with critical comments. The section "How to Use the Tables" has been brought up to date; a few methods have been added. Limits of error are now sometimes given. A new feature in the organic section is a Functional Group Index, covering also the 1964 Tables, and a table of 34 macromolecular organic ligands, including albumin, DNA, RNA, and insulin.

$* * * * * * * * * *$

76. Silvester, L, F., and Pitzer, K. S.

Thermodynamics of Geothermal Brines.

$\mathrm{NaCl}$ (aq) Solutions from 0 to $300{ }^{\circ} \mathrm{C}$

(National Technical Information Service, Report No. LBL-4456, U. S. Department of Commerce, Springfield, VA)

Osmotic and activity coefficient data, enthalpy data, and heat capacity data on aqueous sodium chloride solutions covering the temperature range 0 to $300{ }^{\circ} \mathrm{C}$ were used to obtain the coefficients of an equation that could be used to predict these thermodynamic properties over the indicated temperature range. Tabulated are values of the total Gibbs energy, enthalpy, and heat capacity, partial molal and excess thermodynamic properties for sodium chloride in water from 0 to $300{ }^{\circ} \mathrm{C}$ and from 0 to $6 \mathrm{molal}$.

$* * * * * * * * * * x^{2}$

77. Skinner, H. A. (editor)

III, II

MTP International Review of Science - Volume 10. Thermochemistry and Thermodynamics (Butterworths, London, 1972)

Al though this book contains few tables of thermodynamic data, it does contain several chapters of interest. These chapters are:

Author(s)

I. Wadsö

R. F. Jameson

\section{Chapter}

Biochemical Thermochemistry

Thermodynamics of Metal-Complex Formation 
77. (continued)

Author(s)

G. Pilcher

K. P. Mishchenko

B. J. Zwolinski and J. Chao

\section{Chapter}

Thermochemistry of Chemical Compounds

Thermodynamics of Electrolyte Solutions

Critically Evaluated Tables of Thermodynamic Data

The latter article provides a very useful guide to much of the evaluated thermodynamic data that is not covered in this bibliography.

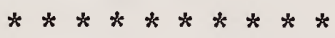

Smith, R. M., and Martel, R. E. -- see entry no. 52 $* * * * * * * * * *$

78. Sober, H. A. (editor)

Handbook of Biochemistry - Selected Data for Molecular Biology

I, II

(The Chemical Rubber Co., Cleveland, 1968) (see also second edition, 1970)

This compendium contains the following twenty-three tables of thermochemical data. The same tables, some containing additional information are in the second edition (indicated in parentheses).

\section{Author or Source}

From "The Chemistry of the Amino Acids and Proteins", C.L.A. Schmidt (editor), Charles C. Thomas Co., Springfield, IL

\section{Table}

Coefficients of Solubility Equations of Certain Amino Acids in Water

Solubility data for 34 amino acids are fitted to equations giving the solubility as a function of temperature

J. 0. Hutchens

Heat Capacities, Absolute Entropies, and

Entropies of Formation of Amino Acids and

Related Compounds

$C_{\mathrm{p}}{ }^{\circ}, S^{\circ}$, and $\Delta S_{f}^{\circ}$ at $25{ }^{\circ} \mathrm{C}$ are tabulated for 28 amino acids, 3 peptides, 4 proteins, and 3 related substances.

J. O. Hutchens and E. P. Kirby Hade, Jr.

Solubilities of Amino Acids in Water at Various Temperatures

The solubilities of 18 amino acids are tabulated at four different temperatures from 1 to $40{ }^{\circ} \mathrm{C}$.

J. 0. Hutchens

Heats of Combustion, Enthalpy and Free Energy

of Formation of Amino Acids and Related Compounds

Enthalpies of combustion and formation and Gibbs energies of formation at $25{ }^{\circ} \mathrm{C}$ are tabulated for 45 amino acids and related compounds.

J. 0 . Hutchens

Heats of Solution of Amino Acids in Aqueous Solution at $25{ }^{\circ} \mathrm{C}$

The heats of solution for 37 amino acids at $25{ }^{\circ} \mathrm{C}$ are tabulated. 
78. (continued)

Author or Source

Table

J. O. Hutchens

Free Energies of Solution and Standard Free Energies of Formation of Amino Acids in Aqueous Solution at $25{ }^{\circ} \mathrm{C}$

Gibbs energies of solution and formation at $25{ }^{\circ} \mathrm{C}$ are given for 18 amino acids.

J. 0. Hutchens

Activities of Amino Acids and Peptides at $25{ }^{\circ} \mathrm{C}$

Molal activity coefficients at $25^{\circ} \mathrm{C}$ are tabulated as a function of molality for 14 amino acids.

From K. S. Markley, "Fatty Acids.

Solubility of Fatty Acids in Water

Part I", second edition,

Interscience, New York (1960)

The solubilities of 13 fatty acids in water at five temperatures from 0 to $60{ }^{\circ} \mathrm{C}$ are tabulated.

From K. S. Markley, "Fatty Acids.

Approximate Solubilities of Water in Saturated

Part I", second edition,

Interscience, New York (1960)

Fatty Acids at Various Temperatures

The approximate solubilities of water in thirteen saturated fatty acids at various temperatures is given.

From K. S. Markley, "Fatty Acids.

Part I", second edition,

Interscience, New York (1960)

Tabulated are solubilities of five saturated triglycerides in various non-aqueous solvents and at a variety of temperatures.

From K. S. Markley, "Fatty Acids.

Part I", second edition

Interscience, New York (1960)

Solubilities of Simple Saturated Triglycerides

Tabulated are solubilities of four mixed triacid triglycerides in four non-aqueous solvents.

P. A. Loach

Oxidation-Reduction Potentials, Absorbance Bands in Biochemical Studies

Oxidation-reduction potentials at ambient temperatures for an assortment of 253 couples frequently encountered in biochemical studies are tabulated with appropriate references.

R. W. Henderson and T. C. Morton

Oxidation-Reduction Potentials of Hemoproteins and Metalloporphyrins

Tabulated are oxidation-reduction potentials for 241 (282) hemoproteins and metalloporphyrins at assorted temperatures. 
78. (continued)

Author or Source

R. M. Izatt and J. J. Christensen
Table

Heats of Proton Ionization and Related Thermodynamic Quantities

This section is an extensive tabulation of enthalpy and entropy changes and $\mathrm{p} K$ values for organic and biochemical systems with 323 (418) references to the literature.

G. C. Krescheck

Calorimeteric $\triangle H$ Values Accompanying Conformational Changes of Macromolecules in Solution

Tabulated are $\Delta H$ values accompanying the conformation changes of 25 macromolecular systems.

W. P. Jencks

Free Energies of Hydrolysis and Decarboxylation

A discussion is given of standard states appropriate to biochemical thermodynamics.

Tabulated are Gibbs energies of hydrolysis of esters of acetic acid and related compounds, of thiol esters, amides, phosphates, and of glycolysis (and of decarboxylation).

W. P. Jencks and J. Regenstein

Ionization Constants of Acids and Bases

Given is an extensive tabulation of $\mathrm{p} K$ values for ionization of several hundred acids and bases with 116 (117) references to the literature.
R. G. Bates
Measurement of $\mathrm{pH}$
R. G. Bates
Buffer Solutions

$\mathrm{pH}$ values have been assigned to several important buffer systems.

Good, Winget, Winter, Conno11y, Izawa, and Singh, Biochemistry, $\underline{5}, 472(1966)$
Properties of Some New Buffers for Biological Research

Tabulated are $\mathrm{p} K$ values with temperature coefficients and metal-buffer binding constants for several buffers useful for biological research.

$$
* * * * * * * * * * *
$$

79. Stephen, H., and Stephen, T.

Solubilities of Inorganic and Organic Compounds (in five volumes)

(Pergammon Press, Oxford, 1963)

This series of flve volumes (about 5500 pages) is a selection from the literature of data on the solubilities of elements, inorganic compounds, and organic compounds in binary, ternary, and multi-component systems. References are given to sources of data in the 1iterature. The data are unevaluated.

$$
* * * * * * * * * * *
$$

Stull, D. R. -- see entry no. 101 .

$$
* * * * * * * * * *
$$


This monograph is divided into three parts. The first part gives theoretical basis and principles of thermodynamics and thermochemistry, some experimental and computational methods used, and some applications to industrial problems. The second part gives thermal and thermochemical properties in the ideal gas state from 298 to $1000 \mathrm{~K}$. In this section, the sources of data are listed and discussed and standardized tables are presented for 918 organic compounds. Values of $C \mathrm{P}^{\circ}, S^{\circ},-\left(G-H^{\circ} 298\right) / T, H^{\circ}, H^{\circ} 298, \Delta H_{\mathrm{f}}^{\circ}, \Delta G_{\mathrm{f}}^{\circ}$, and $\log K_{\mathrm{p}}$ are given at $100 \mathrm{~K}$ intervals. In the third section are listed selected values of enthalpy of formation, entropy, and consistent values of $\Delta G_{f}^{\circ}$ and $\log K \mathrm{p}$ of organic compounds at $298 \mathrm{~K}$. In excess of 4000 compounds are listed. A very few inorganic compounds are also found in this book. A chapter very briefly discusses methods of estimating thermodynamic quantities.

$* * * * * * * * * *$

81. Tatevskii, V. M., Benderskii, V. A., and Yarovoi, S. S. III, III Rules and Methods for Calculating the Physico-Chemical Properties of Paraffinic Hydrocarbons

(Pergamon Press, New York, Oxford, London, Paris, 1961) Translated from the Russian Zakonomernosti $i$ metody rascheta fiziko-khimicheskikh svoistv parafinovykh uglevodorodov (Gostoptekhizdat, Moscow, 1960)

This monograph is a summary and a consolidation of the results of some years of work by Tatevskii and others, extending and elaborating some procedures introduced by Rossini and others. It suffers from ambiguity of statement which is somewhat distracting, but the methods presented in it have been attracting increasing attention recently. Properties calculated include: molar volume, molar refraction, vapor pressure, enthalpy of formation from atoms or elements, Gibbs energy of formation, and enthalpy of combustion. Three different methods are used. Tables of constants and illustrations of the accuracy of the methods are given.

$$
* * * * * * * * * *
$$

82. Timme rmans, $\mathrm{J}$.

Physico-Chemical Constants of Pure Organic Compounds (in two volumes)

II, III

(Elsevier Publishing Co., Amsterdam, 1950 and 1965)

These two volumes contain tables of physical data for pure organic compounds. The arrangement of the data is by compound. Properties tabulated include vapor pressure, boiling point, triple point, viscosity, specific heat, critical constants, density, compressibility, refractive index, enthalpy of vaporization, and dielectric constant.

$* * * * * * * * * * *$

83. Timme rmans, $\mathrm{J}$.

The Physico-Chemical Constants of Binary Systems in Concentrated Solutions

II, II

(in four volumes)

(Interscience Publishers, New York, 1959)

These volumes contain extensive tabulations of physical data relevant to concentrated solutions of binary systems, both organic and inorganic. The properties that are tabulated include dielectric constant, viscosity, equivalent conductivity, surface tension, diffusion and thermal diffusion coefficients, vapor pressure, specific heat, electrochemical data, enthalpy of combustion, enthalpy of dilution and solution, transition enthalpies, and other 
83. (continued)

properties. This reference contains extensive tabulations of data pertinent to water and electrolyte solutions. The data are well organized and there is a general compound index as well as references to the original data sources. The literature coverage is through the year 1957 .

$\star * * * * * * * * *$

Travers, J. G., Dellieu, I., and Hepler, L. G. -- see entry no. 102

$* * * * * * * * * *$

84. Wagman, D. D., Evans, W. H., Parker, V. B., and (in various individual

II, II

parts) Halow, I., Bailey, S. M., Schumm, R. H., Churney, K. L.

Selected Values of Chemical Thermodynamic Properties

National Bureau of Standards Technical Note 270, October 1965 (and continuing)

(U. S. Government Printing Office, Washington, DC 20402)

This technical note is a revision of NBS Circular 500 Part I (see above) and is issued in parts as segments of the work relating to selected sequences of elements are completed.

The following parts had been issued as of 1974 .

270-1 Tables for the first twenty-three elements in the standard order of arrangement.

270-2 Tables for elements 24-32 in the standard order of arrangement.

270-3 Tables for the first thirty-four elements in the standard order of arrangement. This table includes thermochemical data for compounds containing one or two carbon atoms. This technical note supersedes technical notes $270-1$ and $270-2$.

270-4 Tables for elements 35-53 in the standard order of arrangement.

270-5 Tables for elements 54-61 in the standard order of arrangement.

270-6 Tables for the alkaline earth elements, elements 92-97 in the standard order of arrangement.

270-7 Tables for the Lanthanide (Rare Earth) elements, elements 62-76 in the standard order of arrangement.

The remaining elements are to be covered in two or three additional parts to appear over a period of about two years. Documentation and references have not yet been issued.

This is the most comprehensive recent compilation in English of critically evaluated thermochemical data at $298.15 \mathrm{~K}$ for inorganic substances. All inorganic substances and organic substances containing two carbon atoms or fewer per molecule are included if thermodynamic data exist for calculating any of the properties tabulated. The coverage when complete will be approximately 12,000 substances. Properties tabulated are $\Delta H_{\mathrm{f}}{ }^{\circ} 0$, $\Delta H_{\mathrm{f}}{ }^{\circ} 298, \Delta G_{\mathrm{f}}{ }^{\circ} 298, H^{\circ} 298.15-H^{\circ}{ }_{0}, S^{\circ} 298, C_{\mathrm{p}}{ }^{\circ} 298.15$. The data from original sources have been critically evaluated by competent thermochemists and "best" values selected for the functions tabulated, maintaining internal consistency by the relationships $\Delta G_{\mathrm{f}}{ }^{\circ} 298=$ $\Delta H_{\mathrm{f}}{ }^{\circ} 298-T \Delta S_{\mathrm{f}}{ }^{\circ} 298$, and $\Delta H_{\mathrm{f}}{ }^{\circ} 298-\Delta H_{\mathrm{f}}{ }^{\circ} 0=\Sigma\left(H^{\circ} 298-H_{0}^{\circ}\right)$. 
85. Washburn, E. W. (editor-in-chief)

III, I

International Critical Tables of Numerical Data, Physics, Chemistry, and Technology

(McGraw-Hill Book Company, Inc., New York, 1930)

This large (seven volume) but largely superseded compendium of information contains still valid tables of thermodynamic data as well as useful references to the older literature. The tables are arranged according to property with groups of tables being arranged according to discipline. One volume of this series is an index of the materials whose properties are dealt with.

$\star * * * * * * * * *$

86. Westrum, E. F. (editor)

Bulletin of Thermodynamics and Thermochemistry

III, I

(University of Michigan, Ann Arbor, Michigan)

The 18th annual issue appeared in 1975. The Bulletin is a current awareness bibliography of articles that pertain to thermodynamics and thermochemistry. The Bulletin is presently divided into sections on inorganic systems, organic systems, organic systems (mixtures), and, since 1971, biological and macromolecular systems. Also included are sections on work in progress at various laboratorles, substance-property indexes, and bibliographies on books of interest to thermodynamicists. No data values are given. Prior to the issuance of the Bulletin, the yearly volumes of the Annual Reviews of Physical Chemistry, published since 1950 by Annual Reviews, Inc., Palo Alto, California, usually contained bibliographic information dealing with general thermochemistry and the thermodynamics of electrolyte solutions. These articles were the forerunners of the Bulletin of Thermodynamics and Thermochemistry.

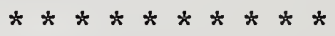

87. Wilhelm, E., and Battino, R.

Thermodynamic Functions of the Solubilities of Gases in Liquids at $25{ }^{\circ} \mathrm{C}$

III, I

Chemical Reviews, 73, 1 (1973)

This review article contains selected values for the solubility, entropy, and enthalpy changes on solution for 16 gases in 39 non-aqueous solvents. Also given are the coefficients of polynomial expressions for the Gibbs energy of solution for a gas in a given solvent as a function of temperature.

$* * * * * * * \frac{1}{*} * \frac{1}{*}$

88. Wilhoit, R. C., and Zwolinski, B. J.

II, III

Handbook on Vapor Pressures and Heats of Vaporization of Hydrocarbons and Related

Compounds (API 44 - TRC)

(Thermodynamics Research Center, Texas A and M Research Foundation, College Station, Texas, 1971)

This handbook gives subject data on 680 hydrocarbons, 95 sulfur compounds, and water from 0 to $150{ }^{\circ} \mathrm{C}$. It is indexed by compound name, and by boiling point. 
89. Wilhoit, R. C., and Zwolinski, B. J.

Physical and Thermodynamic Properties of Aliphatic Alcohols

Journal of Physical and Chemical Reference Data, 2 (Supplement No. 1), I (1973)

This review contains critically evaluated values of the vapor pressure, heat capacity, enthalpies of transition, entropies, thermodynamic functions for the real and ideal gases, densities, refractive indexes, and critical properties for 722 alcohols in the carbon range $\mathrm{C}_{1}$ to $\mathrm{C}_{50}$. This comprehensive review is 420 pages long and lists $2036^{\circ}$ references.

$* * * * * * * * * * *$

90. Wu, Y. C., and Hamer, W. J.

Electrochemical Data. Part XIV. Osmotic Coefficients and Mean Activity Coefficients of a Series of Uni-Bivalent and Bi-Univalent Electrolytes in Aqueous Solutions at

$25{ }^{\circ} \mathrm{C}$. Part XVI. Osmotic Coefficients and Mean Activity Coefficients of a Number of Uni-Trivalent and Tri-Univalent Electrolytes in Aqueous Solution at $25{ }^{\circ} \mathrm{C}$

(National Bureau of Standards Reports No. 10052 and 10088, U. S. Department of Commerce, 1969)

These reports give values for the osmotic and mean activity coefficients of uni-bivalent, vi-univalent, uni-trivalent, and tri-univalent electrolytes in aqueous solution at $25{ }^{\circ} \mathrm{C}$. In each case, the values tabulated are those calculated by fitting the literature data to the equation for the excess Gibbs energy, and represents a good fit to the experimental data. Literature references are included.

$$
\star \star \star * * \star * * * * *
$$

91. Yatsimirskii, K. B., and Vasil'ev, V. P. Instability Constants of Complex Compounds

(Consultants Bureau, New York, 1966) and

(Pergammon Press, New York, 1960)

This volume contains an extensive tabulation of equilibrium data ( $K$ and $-\log K$ ) and enthalpies of formation for processes involving the more common ions and ligands in aqueous solution. Specified are the temperature, ionic strength, and method of measurement with reference(s) to the appropriate literature. The tables contain instability constants for 138 predominantly inorganic complexes.

$* * * * * * * * * * *$

92. Zordan, T. A., and Hepler, L. G.

Thermochemistry and Oxidation Potentials of Manganese and Its Compounds

III, II

Chemical Reviews, 68 , 737 (1968)

This review contains selected values of $\Delta G_{f}{ }^{\circ}, \Delta H_{f}{ }^{\circ}, S^{\circ}$, and electrochemical potentials for manganese and about 45 of its inorganic compounds and aqueous species at $25^{\circ} \mathrm{C}$. Included are the more important aqueous species and references to the primary literature. 
93. Baes, C. F., Jr., and Mesmer, R. E.

(John Wiley \& Sons, New York, 1976)

This book on the chemistry of hydrolysis of inorganic cations contains a substantial amount of equilibrium data pertinent to hydrolysis reactions. For each of the elements which produces a cation or cations in aqueous solution, the available equilibrium data for the hydrolysis reaction(s) at or about $298 \mathrm{~K}$ has been critically assessed in order to obtain "best" values for equilibrium constants and quotients applicable to a given medium. When available, $\Delta H$ and $\Delta S$ data for the hydrolysis reactions are also presented. The data, with references and comments, is arranged under the element of interest.

* $* * * * * * * * *$

94. Bates, R. G.

Determination of $\mathrm{pH}$, Theory and Practice (Second Edition)

II, II

(John Wiley \& Sons, New York, 1973)

This book, the primary topic of which is the establishment of an operational pH scale, contains several tables of interest. Tabulated are the ion product of water from 0 to $60{ }^{\circ} \mathrm{C}$, the vapor pressure, density, and dielectric constant of water from 0 to $100{ }^{\circ} \mathrm{C}$, dielectric constants of pure liquids, and $\mathrm{pH}$ values of several aqueous buffer systems.

$* * * * * * * * * * *$

95. Boublik, T., Fried, V., and Hala, E.

II, III

The Vapour Pressures of Pure Substances

(E1sevier, New York, 1973)

Data are presented in the form of constants for the Antoine equation for the temperature dependence of the vapor pressures of 806 substances in the normal and low pressure region. Almost all of the substances contain carbon. Experimental data from selected original sources are given, together with smoothed values obtained from the Antoine equations at the same temperature, and the absolute and percentage deviations. Standard deviations are calculated. A standard boiling point is calculated for each substance.

$\dot{*} \dot{*} * \dot{*} * \dot{*} \dot{*} \dot{*}$

96. Gedansky, L. M., Woolley, E. M., and Hepler, L. G.

III, II

Thermochemistry of Compounds and Aqueous Ions of Copper

Journal of Chemical Thermodynamics $\underline{2}, 561$ (1970)

This article is a critical review and selection of thermochemical data for the element copper and about 90 of its compounds and aqueous species. Tabulated are selected values of $\Delta H_{\mathrm{f}}{ }^{\circ}, \Delta G_{\mathrm{f}}{ }^{\circ}, S^{\circ}$ and electrode potentials at $25^{\circ} \mathrm{C}$. There are 89 references to the primary literature. 
97. Ingraham, L. L., and Pardee, A. B.

Free Energy and Entropy in Metabolism in Metabolic Pathways, Volume I

(D. M. Greenberg, editor)

(Academic Press, New York, 1967)

This chapter contains a general discussion of the thermodynamics of metabolic processes, with the (unevaluated) data itself being presented in the course of the discussion. The emphasis is almost entirely upon Gibbs energy changes measured under physiological or near physiological conditions. There are 143 references to the primary literature.

$$
* * * * * * * * * * *
$$

98. Jazimirski (Yatsimirskii), K. B .

III, II

The rmochemie von Komplexverbindungen

(Akademie-Verlag, Berlin, 1956) translated from the Russian by Georg Crull

Thermochimia Complexnik Coedinenie

(AKAD NAUK CCCP, MOCKVA 1951)

This monograph correlates thermochemical data of complex compounds in terms of gas, crystal, and solution models emphasizing ionic radii. More than 1400 substances are considered. In summary tables, 52 metal cations, 33 neutral ligands, and 25 anions have enthalpies of formation listed, usually for gaseous and aqueous state. The compounds formed from these ions and ligands are listed usually with the enthalpy of formation of the crystal, and for many of them enthalpies of solution at infinite dilution are given. The chapters discuss and give tables and correlations of hydration enthalpies of cations, anions and some amine salts, ion entropies in solution, enthalpies of formation and solution, energies of gas and crystal ions, binding energies of $\mathrm{H}_{2} \mathrm{O}, \mathrm{NH}_{3}$ and other molecules to central metal ions in gaseous complex ions and similar binding energies.

$* * * * * * * * * * *$

99. Keenan, H. J., Keyes, F. G., Hill, P. G., and Moore, J. G.

III, II

Steam Tables - Thermodynamic Properties of Water, Including Vapor, Liquid, and

Solid Phases (International Edition, Metric Units)

(John Wiley \& Sons, New York, 1969)

This book presents the results of a new and independent correlation of the thermodynamic data for water. It is a complete revision of the Keenan and Keyes Tables of 1936 . Values are tabulated for the specific volume, internal energy, and enthalpy, as functions of temperature and pressure. Also given are data for vapor-liquid and vapor-solid equilibrium, superheated vapor, and the compressed liquid. Mollier and temperature-entropy charts are included along with charts of heat capacity of liquid and vapor. Prandt1 number, and isentropic expansion coefficient. The data and tables are discussed in an appendix of 25 pages and a list of 37 references is given. 
100. Naoomov, G. B., Rhizhenko, B. N., and Kodakovskii, I. L.

Handbook of Thermodynamic Quantities

(In Russian)

(Atomizdat, Moscoẁ, 1971)

This reference book contains a compilation of thermodynamic data for about 2000 chemical compounds and aqueous ions (mostly inorganic). The thermodynamic properties tabulated are $\Delta G_{\mathrm{f}}{ }^{\circ}, \Delta H_{\mathrm{f}}{ }^{\circ}, S^{\circ}$, and $C_{\mathrm{p}}{ }^{\circ}$ at $298 \mathrm{~K}$; electrode potentials; enthalpies and entropies for phase transitions; $\Delta G_{\mathrm{f}}{ }^{\circ}$ of inorganic aqueous ions from 25 to $350{ }^{\circ} \mathrm{C}$; partial molal heat capacities from 10 to $130{ }^{\circ} \mathrm{C}$; and the partial molal volumes of aqueous electrolytes at high temperatures and pressures. There are 1550 references given to the primary literature and to the literature evaluations of others.

$* \star * * * * * * * *$

101. Stull, D. R.

Vapor Pressure of Pure Substances. Organic Compounds

II, III

Industrial and Engineering Chemistry 39, 517 (1947)

and

Vapor Pressure of Pure Substances. Inorganic Compounds

Industrial and Engineering Chemistry 39, 540 (1947)

These articles contain evaluated vapor pressure data on over 1200 organic and 300 inorganic compounds. Given for each compound are those temperatures at which the compound has a given vapor pressure.

$$
* * * * * * * * * *
$$

102. Travers, J. G., Dellieu, I., and Hepler, L. G.

III, II

Scandium: Thermodynamic Properties, Chemical Equilibria, and Standard Potentials Thermochimica Acta 15, 89 (1976)

This article is a critical review and selection of thermochemical data for the element scandium and its compounds including aqueous species. Tabulated are selected values of $\Delta H_{\mathrm{f}}{ }^{\circ}, \Delta G_{\mathrm{f}}{ }^{\circ}, S^{\circ}$ and electrode potentials at $25^{\circ} \mathrm{C}$. There are 79 references to the primary lite rature. 


\begin{tabular}{|c|c|c|c|}
\hline & & & \\
\hline Acke rmann, $\mathrm{T}$. & 10 & CODATA & 16 \\
\hline Aikens, D. A. & 53 & Coetzee, J. T. & 17 \\
\hline Alberty, R. A. & 1 & Cohen, P. 0. & 24 \\
\hline Anderson, H. L. & 26 & Connolly, T. N. & 78 \\
\hline Andrussow, $\mathrm{K}$. & 46 & Covington, A. K. & 19 \\
\hline Armstrong, G. T. & 2 & Cox, J. D. & 20,63 \\
\hline Arnett, E. M. & 17,71 & Cruickshank, F. R. & 7 \\
\hline Arnett, R. L. & 71 & & \\
\hline Ashcroft, S. J. & 3 & Datta, S. P. & 51 \\
\hline Atkinson, G. & 29 & Davies, C. W. & 29 \\
\hline Atkinson, M. R. & 24 & Dellieu, I. & 102 \\
\hline & & DeWane, H. J. & 30 \\
\hline Bailey, S. M. & 84 & Domalski, E. S. & 2,21 \\
\hline Barnes, D. S. & 63 & Dorsey, N. E. & 22 \\
\hline Baes, C. F., Jr. & 93 & Dymond, J. H. & 23 \\
\hline Bates, R. G. & $53,78,94$ & & \\
\hline Battino, R. & $4,5,87$ & Eagland, D. & 26 \\
\hline Beckett, C. W. & 72 & Eatough, D. J. & 14 \\
\hline Benderskii, V. A. & 81 & Ebert, J. P. & 72 \\
\hline Benson, S. W. & 6,7 & Evans, W. H. & 73,84 \\
\hline Bergman, G. A. & 27 & & \\
\hline Bichowsky, F. R. & 8 & Florkin, M. & 24 \\
\hline Bondi, A. & 9 & Fox, D. & 25 \\
\hline Boublik, T. & 95 & Franks, F. & 26 \\
\hline Bowers, V. A. & 53 & Fried, V. & 95 \\
\hline Brewer, L. & 49 & Friedman, H. L. & 26 \\
\hline Brown, H. D. & 10 & Furukawa, G. T. & 2 \\
\hline Brown, G. W., Jr. & 24 & & \\
\hline B rown, R. M. & 71 & Garvin, D. & 60 \\
\hline Burton, $\mathrm{K}$. & 47,51 & George, P. & 67 \\
\hline & & Glushko, V. P. & 27 \\
\hline Cabib, E. & 24 & Goldberg, R. N. & 28 \\
\hline Cardini, C. E. & 24 & Golden, D. M. & 7 \\
\hline Chao, J. & 77 & Good, N. E. & 78 \\
\hline Chapman, T. W. & 11 & Guggenheim, E. A. & 34 \\
\hline Charlot, G. & 12 & Gurvich, L. V. & 27 \\
\hline Christensen, J. J. & $13,14,38,78$ & Grzybowski, A. K. & 51 \\
\hline Churney, K. L. & 84 & & \\
\hline Clark, W. M. & 15 & Hade, K., Jr. & 78 \\
\hline Clever, H. L. & 5 & Hala, E. & 95 \\
\hline
\end{tabular}




\begin{tabular}{|c|c|c|c|}
\hline Halow, I. & 84 & Kornberg, H. L. & 47 \\
\hline Hamer, W. J. & $20,29,31,32,90$ & Kortum, G. & 46 \\
\hline Hamed, H. S. & $29,33,34$ & Krebs, H. A. & 47 \\
\hline Haugen, G. R. & 7 & Krescheck, G. C. & 78 \\
\hline Haẉkins, D. T. & 35 & Krishnan, C. V. & 26 \\
\hline Head, A. J. & 63 & & \\
\hline Henderson, R. W. & 78 & Labes, M. M. & 25 \\
\hline Hepler, L. G. & $\begin{array}{c}17,28,36,37,92,96 \\
102\end{array}$ & $\begin{array}{l}\text { Lange, E. } \\
\text { Larson, J.W. }\end{array}$ & $\begin{array}{l}29 \\
17\end{array}$ \\
\hline Hill, J. 0. & 37 & Latimer, W. M. & 48 \\
\hline Hill, P. G. & 99 & Laughton, P. M. & 17 \\
\hline Hogfeldt, E. & $75^{\circ}$ & Lax, E. & 74 \\
\hline Horne, R. A. & 56 & Leloir, L. F. & 24 \\
\hline \multirow[t]{2}{*}{ Hutchens, J. 0 . } & \multirow{2}{*}{78} & Levine, $\mathrm{S}$. & 73 \\
\hline & & Lewis, G. N. & 49 \\
\hline Ingraham, L. L. & 97 & Linke, W. F. & 50 \\
\hline Iseard, B. S. & 63 & Loach, P. A. & 78 \\
\hline Izatt, R. M. & $13,14,38,78$ & Long, $\mathrm{C}$. & 51 \\
\hline Izawa, S. & 78 & Markley, K. S. & 78 \\
\hline Jaffe, I. & 73 & Marte11, A. E. & 52,75 \\
\hline Jameson, R. F. & 77 & Mason, $\mathrm{H}$. & 24 \\
\hline Janz, G. J. & 39,40 & McCullough, J.P. & 25 \\
\hline \multicolumn{2}{|c|}{ Jazimirski(Yatsimirskii), K.B.98 } & McKelvey, D. R. & 17 \\
\hline Jencks, W. P. & 78 & Medvedev, V. A. & 27 \\
\hline Jordon, T. E. & 41 & Meites, L. & 53 \\
\hline \multirow[t]{2}{*}{ Joshi, R. M. } & \multirow{2}{*}{$\begin{array}{l}41 \\
42\end{array}$} & Mesmer, R. E. & 93 \\
\hline & & Merril1, A. L. & 54 \\
\hline Karpet'yants, M. Kh. & 43 & Miller, D. G. & 34,55 \\
\hline Karapet'yants, M. L. & 43 & Millero, F. J. & 56,57 \\
\hline Kaufmann, D. W. & 44 & Mills, R. & 34 \\
\hline Kazavchinskii, Ya. Z. & 45 & Mischenko, K. P. & 58,77 \\
\hline $\operatorname{Ke} 11$, G. S. & 26 & Moore, J. G. & 99 \\
\hline Keenan, H. J. & 99 & Mortimer, C. T. & 3 \\
\hline Kessel'man, P. M. & 45 & Morton, R. K. & 24 \\
\hline Keyes, F. G. & 99 & Morton, T. C. & 78 \\
\hline Kilpatrick, J. E. & 72 & & \\
\hline King, E. J. & 34 & Naoomov, G. B. & 100 \\
\hline Kirillin, V. A. & 45 & Newman, J. & 11 \\
\hline Kodakovskii, I. L. & 100 & & \\
\hline
\end{tabular}


Olofsson, G.

Ono, $\mathrm{S}$.

O'Neal, H. E.

Owen, B. B.

Pardee, A. B.

Parker, V. B.

Parsons, R.

Pauling, L.

Pedley, J. B.

Perrin, D. D.

Phillips, R. G.

Pilcher, G.

Pimentel, G. C.

Pitzer, K. S.

Poltoratzkii, G. M.

Pourbaix, M.

Randal1, M.

Regenstein, J.

Reid, D. S.

Reid, R. C.

Reilly, C. N.

Reilly, M. L.

Rhizhenko, B. N.

Ritchie, C. D.

Riukin, S.

Robertson, R. E.

Robinson, R. A.

Rogers, A. S.

Rossini, F. D.

Rutman, R. J.

Rytting, J. H.

Schafer, D.

Schmidt, C. L. A.

Schumm, R. H.

Shaw, R.

Sheindlin, A. E.

Sherwood, T. K.

Shpil'rain, E. E.
74

36

10

7

33

97

$59,60,84$

61

62

63

64,65

66,67

$20,63,77$

71

$49,71,72,76$

58

68

49

78

26

69

53

2

100

17

45

17

34,70

7

$8,71,72,73$

67

38

78

84

7

45

69

45
Sillen, L. G.

75

Silvester, L. F.

76

Singh, R. M. M.

78

Sinke, G. C.

80

Skinner, H. A.

77,80

Smith, E. B.

23

Smith, R. M.

52,75

Sober, H. A.

78

Spedding, F. H.

29

Stephen, $\mathrm{H}$.

79

Stephen, T.

79

Stokes, R. H.

34,70

Stull, D. R.

80,101

Sychev, V. V.

45

Takahashi, K. 10

Tatevskii, V. M. $\quad 81$

Taylor, W. J.

72

Timmermans, J.

82,83

Timrot, D. L.

45

Tödheide, K.

26

Tomkins, R. P. T.

40

Travers, J. G.

102

Vasil'ev. V. P.

91

Voge1, W.

46

Wadsö, I .

77

Wagman, D. D.

Walsh, R.

$60,73,84$

7

85

54

Watt, B. K.

25

Weisberger, A.

72

We rner, H. C.

$25,80,86$

5,87

$2,10,88,89$

72

78

78

Winter, $W$.

26 
entry

Woolley, E. M.

Worsley, I. G.

Wu, Y. C.

Yarovoi, S. S.

Yatsimirski, K. B.

Zordan, T. A.

Zwolinski, B. J.
96

37

$31,32,90$

81

91,98

92

$42,77,88,89$ 


\section{SUB JECT INDEX}

entry

acetic acid esters

hydrolysis

78

acid constants

75

see also equilibrium constants

acids, inorganic

dissociation constants

thermodynamics in water (and nonaqueous solvents)

$59,64,75,78$

58,59

acids, organic

decarboxylation

78

dissociation constants

hydrolysis of esters

vapor pressures

$17,46,51,53,75,78$

78

41

acids, strong

70

activation energies

polymerization

42

activity coefficients

amino acids

78

from diffusion data

29

inorganic electrolytes

multicomponent electrolyte solutions

$11,18,32,33,34,70$

of rare earths

34

29

organic electrolytes

peptides

$18,32,33,70$

78

sodium chloride in water

76

strong electrolytes

$48,49,70$

uni-polyvalent electrolytes

uni-univalent electrolytes

90

32

adenine nucleotides

66

adenosine

66

adenosine-5'-diphosphate

$1,10,67$ 
albumin

al cohols

Gibbs energy changes $\quad 47$

thermodynamic properties $\quad 89$

vapor pressures $\quad 41$

aldehydes

vapor pressures

alicyclic organic bases

dissociation constants 65

aliphatic organic bases

dissociation constants

alkali metal salts

thermodynamics of solutions $\quad 58,59$

amides

$\begin{array}{ll}\text { hydrolys is } & 78\end{array}$

amino acids

activities 78

enthalpies of combustion $\quad 78$

enthalpies of solution 78

entropies and enthalpies of formation 78

Gibbs energy of formation 78

Gibbs energy of formation in 78

solution

Gibbs energy of solution $\quad 78$

heat capacities, entropies $\quad 78$

Ionization thermodynamics $\quad 17$

solubilities $\quad 78$

thermodynamics in aqueous solution 26

ammonia

metabolism $\quad 24$

ammonium lons

acid ionfzation the rmodynamics

anilines

redox potentials 
anilinium ions

acid ionization thermodynamics

aqueous electrolytes

aromatic organic bases

dissociation constants

barbituric acids

Ionization thermodynamics

base constants

see also equilibrium constants

bases

see also acids

inorganic

organic

thermodynamics in water (and nonaqueous solvents

bibliography

thermodynamic data

water

binary systems

inorganic

organic

physical data

solubilities in

binding constants see also equilibrium constants meta1-buffer complexes

78

biochemical pathways

47

biosynthesis

Gibbs energy changes

24

boiling point

estimation

69

organic compounds
17

$11,17,26,58,59$

65

17

75

$53,58,59,64,78$

$53,65,78$

58,59 


\section{entry}

buffer solutions

$18,51,78$

carbohydrates

isomerization and hydrolysis

10

carboxylic acids

see acids, organic

cations

thermodynamics of hydrolysis

93

$C, H, N, O, P, S$ compounds

2,21

CODATA

16,60

colloids

transport properties

18

combustion energy

$2,20,21,54$

complexes, meta1-1igand

inorganic ligands

$3,13,75$

organic ligands

$3,13,75$

compressibilities

aqueous electrolytes

29

organic compounds

82

conductance

aqueous electrolytes

binary systems

non-aqueous electrolytes

$18,29,30,33,70$

83

40

copper compounds

thermochemistry

96 
creatine

entry

enthalpy of combustion and formation 78

Gibbs energy of formation 78

heat capacity, entropy, entropy 78

of formation

creatinine

enthalpy of combustion and formation 78

entropy of formation $\quad 78$

Gibbs energy of formation $\quad 78$

heat capacity, entropy 78

critical properties

estimation

67,69

organic compounds $\quad 82$

water

density

alcohols $\quad 89$

aqueous electrolytes 29

inorganic electrolytes $\quad 11,18,33,74$

non-aqueous electrolytes $\quad 40$

organic compounds 82

$\begin{array}{ll}\text { organic electrolytes } & 33,74\end{array}$

water 26

deoxyribonucleic acid

38,75

deuterium oxide

physical properties $\quad 40$

thermodynamic properties of 26

electrolytes in

dielectric constants

aqueous electrolyte solutions $\quad 18$

binary systems 83

non-aqueous electrolytes $\quad 40$

of organic compounds 82

of water 26

solvents $\quad 18$

diffusion constants

binary systems

83.

inorganic electrolytes

$11,18,29,33,70$

organic electrolytes

$18,33,70$ 
dilution, enthalpy of

dipole moments

dissociation constants

aqueous electrolytes

inorganic acids and bases

ligands

organic acids, aqueous

organic bases

dyes and indicators bases

dissociation constants

electrochemical data

binary systems

electrochemical potentials

biological oxidation-reduction reactions

copper compounds

in non-aqueous electrolyte solutions

in organic solvents

inorganic substances

manganese compounds

mercury compounds

platinum metal compounds

scandium compounds

vanadium, niobium, and

tantalum compounds

electrode processes

electrolytes

aqueous and non-aqueous

current awareness bulletin

data handbook

dilution of

equilibrium constants of

Gibbs energies, enthalpies, heat capacities and entropies

irreversible thermodynamics

molar volumes

multicomponent systems

non-aqueous

osmotic coefficients

oxidation-reduction potentials

sodium chloride
$27,58,59,84$

18

$18,29,33$

64

75

46,51

65

\section{5}

18

83

47

96

40

70

12,68

92

36

28

102

37

18

$11,18,33,70,77$

49,58

19

61

$27,29,59,84$

$3,13,17,38,46,47,51,53,64,65,75,78$

$3,13,17,26,27,38,47,73,75,84$

55

56,57

26,34

40

$32,70,90$

$15,47,48,75$

40,76 


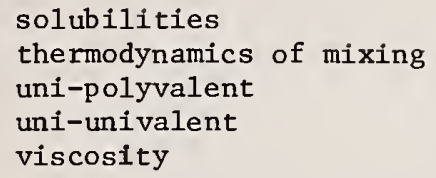

energy transformations in living matter

energy values of foods

enthalpy

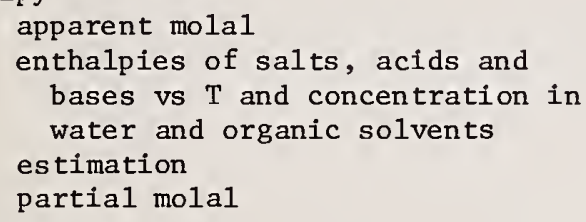

$50,78,79$
26
90
32,59
34

47

54

33

58

9,39

18,49

78

52

$13,38,58$

$2,29,40,58,59,73,83,84$

$2,3,6,7,8,10,16,20,21,26,27,28,36,37,39,42,43$

$48,58,60,63,71,72,73,74,78,80,84,91,92,93,96,98$, 100,102

$6,7,69,74,81$

26,98

93

$17,58,59,78,82$

26

14

42

66

38

52

$2,27,29,58,59,73,78,83,84,98$ 
Enthalpy change (continued)

of solution of hydrocarbons, alcohols, and rare gases in water of solution for non-aqueous electrolytes

entropy

alcohols

amino acids and related compounds aqueous species

copper compounds

dissolved acids, salts, bases in water and non-aqueous solvents estimation

hydrocarbons

inorganic compounds

key values

manganese compounds

mercury compounds

of hydrolysis

of water

organic compounds

platinum metal compounds

scandium compounds

single ion

vanadium, niobium, and tantalum compounds entry

26

40

$2,6,7,10,43$

89

78

27

96

58

$6,7,9,39,48$

71,72

$27,60,73,74,84$

16

92

36

93

26

$27,43,73,74,80,84$

28

102

26

37

entropy change

of binding of metal ions to

52

organic ligands

of complex formation

of dilution

$3,13,38$

$3,36,78$

of formation

of hydration of ions in water

26

$17,58,78$

14

of multidentate macrocyclic compounds

of polymerization

42

of protonation of nucleic acids, 38 nucleotides, and nucleosides

of protonation of organic ligands 52

of solution 2,58

of solution of gases in liquids 87

of solution of hydrocarbons, alcohols 26

and rare gases in water 
enzyme catalyzed reactions

equilibrium constants

acid-base

for amines

for amino acids

for inorganic complexes

meta1 ion-11gand

multidentate macrocyclic compounds

of formation

of hydrolysis

of ion pairing

of polymerization

proton transfer reactions

protonation of adenosine and adenine nucleotides

protonation of nucleic acids, nucleotides, and nucleosides

esters

Gibbs energies of hydrolysis

estimation, properties (various kinds)

ethanol as solvent

thermodynamic properties of acids, bases, salts in

ethanol-water mixtures acid dissociation in

fatty acids solubilities

fermentation

Gibbs energy change

food and foodstuff ingredients composition and energy values entry

$10,47,78$

34,51

52

52

75,91

$13,38,53,75$

14

$73,80,84$

93

29

42

53

66

38

78

$6,7,9,20,39,48,69,80,81,98$

58

47

54 
fugacity

water

gases

diffusion constants in water non-polar, properties estimation

polar, properties estimation

solubility in liquids

solubility in water

Gibbs energy

biological systems

Gibbs energy change ammonia metabolism

biological oxidation-reduction reactions

biosynthesis of saccharides

fermentation

glycolysis

metabolic processes

of decarboxylation

of dilution

of formation

of formation (estimation)

of hydration of ions in water

of hydrolysis

of ionization

of mixing electrolytes

of polymerization

of solution

of solution of hydrocarbons,

alcohols, and rare gases in water phosphates hydrolysis

tricarboxylic acid cycle

urea biosynthesis
$2,3,10$

24

47,51

24

47

47

$24,47,51$

78

2,58

$2,3,10,26,27,28,36,37,43,47,48,58,60,58,71,72$, $73,74,78,80,84,92,96,100,102$

$6,7,69,74,81$

26

78,93

17,58

26

42

$2,58,78$

26

$1,24,67$

47

24

glasses

see solids

glucose

partial molal properties

glucosides

hydrolysis

glycerol

partial molal properties 
entry

glycine

partial molal properties

10

glycolysis

glycosides

hydrolysis

78

group contributions

$6,7,39,74$

half-cel1 potentials

18

heat capacity 10

alcohols $\quad 89$

amino acids and related compounds 78

binary systems $\quad 83$

$\mathrm{C}, \mathrm{H}, \mathrm{N}, \mathrm{O}, \mathrm{P}, \mathrm{S}$ compounds 2

dissolved acids, salts, bases in 58

water and non-aqueous solvents

estimation

partial molal

sodium chloride in water

$6,7,9,39,69$

49,100

76

uni-univalent electrolytes $\quad 59$

water

26

heat capacity change

of complex formation

of hydration of ions in water

of ionization

13,38

26

17

of multidentate macrocyclic

14

compounds

of protonation of nucleic acids,

nucleotides, and nucleosides

of solution of hydrocarbons,

alcohols, and rare gases in water

heat content

see enthalpy

heat of formation

see enthalpy changes of formation

heavy water

see deuterium oxide 
hemoglobin

mobility

hemoproteins

oxidation-reduction potentials

heterocyclic organic bases

dissociation constants

hydrobromic acid

conductance data

hydrochloric acid

conductance data

hydrofluoric acid

conductance data

hydroiodic acid conductance data

hydrogen ion concentration

1,24

hydrolysis

metal ion hydrates

$1,10,47$

of ATP, ADP

75

thermodynamics

67

93

hydroxyl ion

as a ligand

64,75

ice

ionic equilibrium constant

26

transport properties

26

index, substance-property

86

indicator bases

dissociation constants

65

inorganic

electrolytes

ligands

$11,18,27,48,56,58,59,70,73,84$ see ligands 
entry

inorganic compounds 13 chemical bonding

current awareness bibliography

86

solubilities

50,79

thermodynamic properties

$8,12,27,73,74,84$

inorganic 1igands see ligands

instability constants see equilibrium constants

insulin

75

interface potentials

intermolecular forces estimation

international critical tables

ionic strength, effects

$38,53,67$

ionic transport coefficients

ionization

aqueous acids

17,53

ionization constants acids and bases organic acids

isomerization

carbohydrates 
Lennard-Jones potential

see intermolecular forces

ligands

$3,13,53,75$

liquids

$$
\text { properties estimation }
$$

9,69

liquid-junction potentials

macromolecules

as ligands

current awareness bibliography

75

helix-random coil transitions

86

transport properties

10

18

magnesium ion (effects)

$1,24,67$

manganese compounds thermo chemistry

$27,43,84,92$

melting point non-aqueous electrolytes

40

mercury compounds

thermochemis try

$27,36,43,84$

metabolic processes

47,97

metal complexes

hydrated ions

with buffers

with nucleic acids, nucleotides and nucleosides

metalloporphyrins

oxidation-reduction potentials

78

metal-organic compounds

solubilities

50

thermodynamic properties

$6,20,41$

methanol as solvent

thermodynamic properties of salts,

$3,6,13,53,75,77,91$

64

78

38

acids and bases in 
entry

me thanol-water mixtures

acid dissociation in

mixed electrolytes

70

mixed solvent systems

$2,40,53$

mixtures, fluid

current awareness bibliography 86

estimation of properties 69

mobilities

ionic

proteins

18

18

molar volume

see volume

multi-component systems

solubilities in

79

multidentate macrocyclic compounds

14

NAD

redox potentials

15

NADP

redox potentials

15

natural product bases

dissociation constants

65

niobium compounds

the rmochemistry

$27,37,43,84$

nitrogen compounds

enthalpy of formation

$20,27,43,80,84$

non-aqueous solvents

electrolytes in 58

metal-1igand complexes in 75

solubilities in

50 
non-polar gases

see gases

nucletc acids

nucleosides

nucleotides

38

nutrients
see foods

organic bases

dissociation constants

organic compounds

$\mathrm{C}_{2}$ or $\mathrm{C}_{1}$

current awareness bibliography

solubilities

$3,4,18,20,21,25,39,42,43,46,56,74,80,82,101$

$27,73,84$

86

78

organic electrolytes

molar volumes

56

properties

70

thermodynamic quantities

59

organic ligands

see ligands

organo-metallic compounds

see metal organic compounds

osmotic coefficients

inorganic electrolyte

organic electrolytes

sodium chlorides in water

$18,32,70$

18,70

uni-polyvalent electrolytes

76

90

uni-univalent electrolytes

32

oxidation-reduction potentials

biological systems

47,51

hemoproteins and metalloporphyrins

78

organic systems

15

selected

78 
partial molar volumes see volume

peptides activities in aqueous solution $\quad 78$ enthalpy of combustion and formation 78 Gibbs energy of formation 78 heat capacities, entropies $\quad 78$

$\mathrm{pH}$
acid-base equilibria
51
ATP hydrolysis
de termination of
67
94
effect on oxidation reduction
48 potentials
effects on reactions
of buffers
$1,24,38$
78,94

phenols

acid dissociation constants, aqueous 46

ionization the rmodynamics 17

redox potentials $\quad 15$

phosphates

Gibbs energy and biosynthesis $\quad 24$

hydrolysis

phosphorous compounds enthalpy of formation $\quad 27,43,63,84$

physiological energy use

pK values

acids and bases

$53,64,78$

buffers

78

isotope effects

17

platinum metal compounds thermochemistry

$27,28,43,84$

polar gases

see gases 
polarographic data

for non-aqueous electrolyte $\quad 40$

solutions

polymers

polymerization processes

properties estimation

porphyrins

redox potentials

potential diagrams (emf)

elements and compounds

pressure, effect of

on enthalpy, entropy, internal energy, 69

heat capacity, estimation

proteins

heat capacities, entropies $\quad 78$

proton transfer reactions

equilibrium constants, aqueous

53

quinones

15

redox potentials

15

rate constants

polymerization

red cells

mobilities

redox potentials

see oxidation-reduction potentials

refractive index

alcohols

89

organic compounds

82

ribonucleic acid

38,75 
sac charides

salts

thermodynamic properties in water, methanol, ethanol and other organic solvents

thermodynamic properties of uni-univalent in solution

scandium compounds

serum albumin mobility

silicon compounds enthalpy of formation $\quad 24,43,63,84$

sodium chloride

solids

crystalline, properties estimation glasses, properties estimation

solubilities

amino acids

elements, inorganic compounds,

organic compounds

fatty acids in water

gases in liquids

in non-aqueous electrolytes

40

triglycerides

78

water in fatty acids $\quad 78$

solubility constants

75

see also equilibrium constants

spectroscopic data

for non-aqueous electrolyte solutions 40

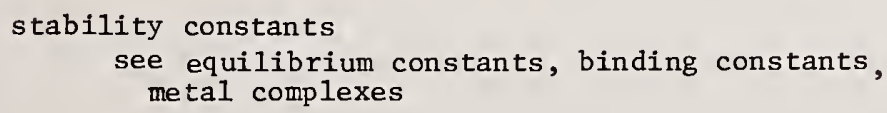


entry

structure, relation to physical properties 9,39

sulfur compounds, organic

88

surface tension

binary systems 83

estimation $\quad 69$

tantalum compounds

thermochemistry

$27,37,43,84$

ternary systems

solubilities in

79

thermal conductivity

of water

26

thiol esters

hydrolysis $\quad 78$

transference number

in non-aqueous electrolytes $\quad 40$

inorganic electrolytes

$11,18,33,74$

organic electrolytes

$18,33,74$

\section{transitions}

coil to helix

26

homopolymer to coil helix

26

transition metal complexes

see metal complexes

transport coefficients, ionic

$54,55,70$

tricarboxylic acid cycle

Gibbs energy changes 
triglycerides

urea

biosynthesis

enthalpy of formation and

78

combustion

Gibbs energy of formation $\quad 78$

partial molal properties

78
10

vanadium compounds

thermochemistry

$27,37,43,84$

vapor pressure

alcohols

aqueous electrolyte solutions

89

binary systems

18

$\mathrm{C}, \mathrm{H}, \mathrm{N}, \mathrm{O}, \mathrm{P}, \mathrm{S}$ compounds

estimation

non-aqueous electrolyte solutions

organic compounds

water

83

2

$9,69,81$

40

$2,25,41,82,88,95,101$

26,88

virial coefficients

23

viscosity

binary systems

estimation

inorganic electrolytes

non-aqueous electrolytes

organic compounds

water

83

9,69

11

40

82

26

volume changes

on hydration of ions in water

on mixing liquids

26

4

volumes, molar

aqueous ions and electrolytes

$56,57,100$

liquids, binary mixtures

liquids, estimation

4

water

69

56,57 
entry

water

bibliography $\quad 35$

treatise on

22,26

thermodynamic properties

99

vapor pressure and enthalpy of

88 vaporization 
NBS-II4A (REV. 7.73)

\begin{tabular}{|c|c|c|}
\hline \begin{tabular}{l|l} 
U.S. DEPT. OF COMM. & 1. PUBLICATION OR REPORT NO. \\
BIBLIOGRAPHIC DATA & NBS SP-454 \\
SHEET & S
\end{tabular} & $\begin{array}{l}\text { 2. Gov't Accession } \\
\text { No. }\end{array}$ & 3. Recipjent's Accession No. \\
\hline \multirow{2}{*}{\multicolumn{2}{|c|}{$\begin{array}{l}\text { 4. TITLE AND SUBTITLE } \\
\text { An Annotated Bibliography of Compiled Thermodynamic Data Sources } \\
\text { for Biochemical and Aqueous Systems (1930 to 1975) } \\
\text { Equilibrium, Enthalpy, Heat Capacity, and Entropy Data }\end{array}$}} & $\begin{array}{l}\text { 5. Publication Date } \\
\text { September } 1976 .\end{array}$ \\
\hline & & 6. Performing Organization Code \\
\hline \multicolumn{2}{|c|}{ 7. AUTHOR(S) George T. Armstrong and Robert N. Goldberg } & 8. Performing Organ. Report No. \\
\hline \multicolumn{2}{|l|}{$\begin{array}{l}\text { 9. PERF ORMING ORGANIZATION NAME AND ADDRESS } \\
\qquad \begin{array}{l}\text { NATIONAL BUREAU OF ST ANDARDS } \\
\text { DEPARTMENT OF COMMERCE } \\
\text { WASHINGTON, D.C. } 20234\end{array}\end{array}$} & $\begin{array}{l}\text { 10. Project/Task/Work Unit No. } \\
\text { 11. Contract/Grant No. }\end{array}$ \\
\hline \multirow{2}{*}{\multicolumn{2}{|c|}{ 12. Sponsoring Organization Name and Complete Address (Street, City, State, ZIP) }} & $\begin{array}{l}\text { 13. Type of Report \& Period } \\
\text { Covered } \\
\text { FINAL }\end{array}$ \\
\hline & & 14. Sponsoring Agency Code \\
\hline
\end{tabular}

Library of Congress Catalog Card Number: 76-608259

16. ABSTRACT (A 200-word or less factual summary of most significant information. If document includes a significant bibliography or literature survey, mention it here.)

Contained herein is a selected and annotated bibliography of sources of compiled and evaluated chemical tnermodynamic data relevant to biochemical and aqueous systems. The principal thermodynamic properties considered herein are Gibbs energy and equilibrium data, enthalpies of formation and reaction, heat capacities and entropies, and the corresponding partial molal properties. Derived quantities used in calculating the above are also included. Transport and mechanical data have also been identified to a lesser degree. Included in the annotations to the data sources are brief descriptions of the types of properties tabulated, the classes of materials dealt with, and the degree of completeness of the compilations.

17. KEY WORDS (six to twelve entries; alphabetical order; capitalize only the first letter of the first key word unless a proper name; separated by semicolons) Aqueous systems; bibliography; biochemical systems; enthalpy data; entropy data; equilibrium data; Gibbs energy data; heat capacity data; partial molal properties; thermochemistry; thermodynamics; review articles; water pollution,

18. AVAILABILITY $\overline{\mathrm{X}}$ Unlimited

For Official Distribution. Do Not Release to NTIS

$\mathrm{X}$ Order From Sup. of Doc., U.S. Government Printing Office Washington, D.C. 20402 , SD Cat. No. C13.10:454

$\square$ Order From National Technical Information Service (NTIS) Springfield, Virginia 22151

\begin{tabular}{|l|c|}
\hline $\begin{array}{l}\text { 19. SECURITY CLASS } \\
\text { (THIS REPURT) }\end{array}$ & 21. NO. OF PAGES \\
UNCL ASSIF IED & 67 \\
\hline $\begin{array}{l}\text { 20. SECURITY CLASS } \\
\text { (THIS PAGE) }\end{array}$ & $\begin{array}{c}\text { 22. Price } \\
\$ 1.65\end{array}$ \\
UNCLASSIFIED & USCOMM-DC 29042-P74 \\
\hline
\end{tabular}





\section{PERIODICALS}

JOURNAL OF RESEARCH reports National Bureau of Standards research and development in physics, mathematics, and chemistry. It is published in two sections, available separately:

- Physics and Chemistry (Section A)

Papers of interest primarily to scientists working in these fields. This section covers a broad range of physical and chemical research, with major emphasis on standards of physical measurement, fundamental constants, and properties of matter. Issued six times a year. Annual subscription: Domestic, $\$ 17.00$; Foreign, $\$ 21.25$.

\section{- Mathematical Sciences (Section B)}

Studies and compilations designed mainly for the mathematician and theoretical physicist. Topics in mathematical statistics, theory of experiment design, numerical analysis, theoretical physics and chemistry, logical design and programming of computers and computer systems. Short numerical tables. Issued quarterly. Annual subscription: Domestic, $\$ 9.00$; Foreign, $\$ 11.25$.

DIMENSIONS/NBS (formerly Technical News Bulletin)-This monthly magazine is published to inform scientists, engineers, businessmen, industry, teachers, students, and consumers of the latest advances in science and technology, with primary emphasis on the work at NBS. The magazine highlights and reviews such issues as energy research, fire protection, building technology, metric conversion, pollution abatement, health and safety, and consumer product performance. In addition, it reports the results of Bureau programs in measurement standards and techniques, properties of matter and materials, engineering standards and services, instrumentation, and automatic data processing.

Annual subscription: Domestic, $\$ 9.45$; Foreign, $\$ 11.85$.

\section{NONPERIODICALS}

Monographs-Major contributions to the technical literature on various subjects related to the Bureau's scientific and technical activities.

Handbooks-Recommended codes of engineering and industrial practice (including safety codes) developed in cooperation with interested industries, professional organizations, and regulatory bodies.

Special Publications-Include proceedings of conferences sponsored by NBS, NBS annual reports, and other special publications appropriate to this grouping such as wall charts, pocket cards, and bibliographies.

Applied Mathematics Series-Mathematical tables, manuals, and studies of special interest to physicists, engineers, chemists, biologists, mathematicians, computer programmers, and other engaged in scientific and technical work.

National Standard Reference Data Series-Provides quantitative data on the physical and chemical properties of materials, compiled from the world's literature and critically evaluated. Developed under a world-wide program coordinated by NBS. Program under authority of National Standard Data Act (Public Law 90-396).

NOTE: At present the principal publication outlet for these data is the Journal of Physical and Chemical Reference Data (JPCRD) published quarterly for NBS by the American Chemical Society (ACS) and the American Institute of Physics (AIP). Subscriptions, reprints, and supplements available from ACS, 1155 Sixteenth St. N. W., Wash. D. C. 20056.

Building Science Series-Disseminates technical information developed at the Bureau on building materials, components, systems, and whoie structures. The series presents research results, test methods, and performance criteria related to the structural and environmental functions and the durability and safety characteristics of building elements and systems.

Technical Notes-Studies or reports which are complete in themselves but restrictive in their treatment of a subject. Analogous to monographs but not so comprehensive in scope or definitive in treatment of the subject area. Often serve as a vehicle for final reports of work performed at NBS under the sponsorship of other government agencies.

Voluntary Product Standards-Developed under procedures published by the Department of Commerce in Part 10, Title 15, of the Code of Federal Regulations. The purpose of the standards is to establish nationally recognized requirements for products, and to provide all concerned interests with a basis for common understanding of the characteristics of the products. NBS administers this program as a supplement to the activities of the private sector standardizing organizations.

Federal Information Processing Standards Publications (FIPS PUBS)-Publications in this series collectively constitute the Federal Information Processing Standards Register. Register serves as the official source of information in the Federal Government regarding standards issued by NBS pursuant to the Federal Property and Administrative Services Act of 1949 as amended, Public Law 89-306 (79 Stat. 1127), and as implemented by Executive Order 11717 (38 FR 12315, dated May 11, 1973) and Part 6 of Title 15 CFR (Code of Federal Regulations).

Consumer Information Series-Practical information, based on NBS research and experience, covering areas of interest to the consumer. Easily understandable language and illustrations provide useful background knowledge for shopping in today's technological marketplace.

NBS Interagency Reports (NBSIR)-A special series of interim or final reports on work performed by NBS for outside sponsors (both government and non-government). In general, initial distribution is handled by the sponsor; public distribution is by the National Technical Information Service (Springfield, Va. 22161) in paper copy or microfiche form.

Order NBS publications (except NBSIR's and Bibliographic Subscription Services) from: Superintendent of Documents, Government Printing Office, Washington, D.C. 20402.

\section{BIBLIOGRAPHIC SUBSCRIPTION SERVICES}

The following current-awareness and literature-survey bibliographies are issued periodically by the Bureau: Cryogenic Data Center Current Awareness Service

A literature survey issued biweekly. Annual subscription: Domestic, $\$ 20.00$; foreign, $\$ 25.00$.

Liquefied Natural Gas. A literature survey issued quarterly. Annual subscription: $\$ 20.00$.

Superconducting Devices and Materials. A literature survey issued quarterly. Annual subscription: $\$ 20.00$. Send subscription orders and remittances for the preceding bibliographic services to National $\mathrm{Bu}$ reau of Standards, Cryogenic Data Center (275.02) Boulder, Colorado 80302. 
POSTAGE ANO FEES PAIO U.S. OEPARTMENT OF COMMERCE $C O M=215$

OFFICIAL BUSINESS

Penalty for Private Use, $\$ 300$
SPECIAL FOURTH-CLASS RATE

BOOK 



